Fire Effects and Fire Control in

Nitrocellulose Photographic-Film Storage

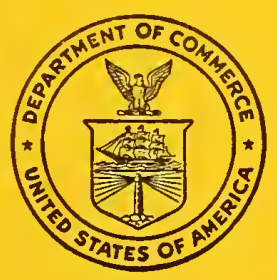

United States Department of Commerce National Bureau of Standards Building Materials and Structures Report 145 


\section{BUILDING MATERIALS AND STRUCTURES REPORTS}

On request, the Superintendent of Documents, U. S. Government Printing Office, Washington $25, \mathrm{D}$. C., will place your name on a special mailing list to receive notices of new reports in this series as soon as they are issued. There will be no charge for receiving such notices.

If 100 copies or more of any report are ordered at one time, a discount of 25 percent is allowed. Send all orders and remittances to the Superintendent of Documents, $U$. S. Government Printing Office, Washington 25, D. C.

The following publications in this series are available by purchase from the Superintendent of Documents at the prices indicated:

BMS1 Research on Building Materials and Structures for Use in Low-Cost Housing .......

BMS2

BMS3

$\mathrm{BMS} 4$

BMS5

BMS6

BMS7

BMS8

Methods of Determining the Structural Properties of Low-Cost House Constructions_-

Suitability of Fiber Insulating Lath as a Plaster Base....

Accelerated Aging of Fiber Building Boards _.......

Structural Properties of Six Masonry Wall Constructions

Survey of Roofing Materials in the Southeastern States.

Water Permeability of Masonry Walls

Methods of Investigation of Surface Treatment for Corrosion Protection of Steel

BMS9 Structural Properties of the Insulated Steel Construction Co.'s "Frameless-Steel" Constructions for Walls, Partitions, Floors, and Roofs.

BMS10 Structural Properties of One of the "Keystone Beam Steel Floor" Constructions Sponsored by the H. H. Robertson Co .

BMS11 Structural Properties of the Curren Fabrihome Corporation's "Fabrihome" Construc-

BMS12 Structural Properties of "Steelox" Constructions for Walls, Partitions, Floors, and Roofs, Sponsored by Steel Buildings, Inc

BMS13

BMS14

Properties of Some Fiber Building Boards of Current Manufacture.

BMS14 Indentation and Recovery of Low-Cost Floor Coverings

BMS16 Structural Properties of a "Tilecrete" Floor Construction Sponsored by Tilecrete Floors, Inc _. Sponsored by the Harnischfeger Corporation

BMS17

BMS18

Sound Insulation of Wall and Floor Constructions
Structural Properties of "Pre-fab" Construction for Walls, Partitions, and Floors Sponsored by Harn ischfeger Corporation .

BMS19 Preparation and Revision of Building Codes
BMS20 Structural Properties of "Twachtman" Constructions for Walls and Floors Sponsored

BMS21 Structural Properties of a Concrete-Block Cavity-Wall Construction Sponsored by the

BMS22 Structural Properties of "Dun-Ti-Stone" Wall Construction Sponsored by the W. E.

BMS23 Structural Properties of a Brick Cavity-Wall Construction Sponsored by the Brick

Manufacturers Association of New York, Inc- Structural Properties of a Reinforced-Brick Wall Construction and a Brick-Tile CavityWall Construction Sponsored by the Structural Clay Products Institute........

BMS25 Structural Properties of Conventional Wood-Frame Constructions for Walls, Partitions, Floors, and Roofs

BMS26 Structural Properties of "Nelson Pre-Cast Concrete Foundation" Wall Construction Sponsored by the Nelson Cement Stone Co., Inc

BMS27 Structural Properties of "Bender Steel Home" Wall Construction Sponsored by the Bender Body Co

BMS28 Backflow Prevention in Over-Rim Water Supplies

BMS29

Survey of Roofing Materials in the Northeastern States Structural Properties of a Wood-Frame Wall Construction Sponsored by the Douglas

Fir Plywood Association
BMS31 Structural Properties of "Insulite" Wall and "Insulite" Partition Constructions

Sponsored by The Insulite Co
BMS32 Structural Properties of Two Brick-Concrete-Block Wall Constructions and a ConcreteBlock Wall Construction Sponsored by the National Concrete Masonry Association.

BMS33 Plastic Calking Materials

"Out of print.

†Superseded by BMS144.

†Superseded by BM\$116. 


\section{Fire Effects and Fire Control in}

\section{Nitrocellulose Photographic-Film Storage}

J. V. Ryan, J. W. Cummings, and A. C. Hutton

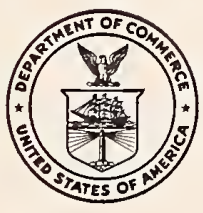

Building Materials and Structures Report 145

Issued April 2, 1956 



\section{Foreword}

Although the manufacture of nitrocellulose film in the United States was discontinued during 1950, large quantities of this type of film containing important information of a historical or record nature were accumulated for many vears and must be preserved. 'The highly flammable character of this film complicates the problems of preservation.

Several investigations have been carried out by various organizations to determine the pressures that were developed in vented chambers during the burnout of loads of nitrocellulose film. However, little if any work has been done to establish the most effective methods of reducing the hazard of such fires. Because the problems of nitrocellulose-film storage were common to many organizations, an Inter-Agency Advisory Cornmittee for Nitrate Film Tault Tests was formed to sponsor a large-scale investigation to provide information for recommendations for safe storage. The committee was composed of representatives from several interested Government and private organizations, such as the National Archives, Department of Defense, Motion Picture Association of America, and the National Automatic Sprinkler and Fire Control Association. This report presents the results of that investigation and the conclusions based thereon.

A. V. Astin, Director. 


\section{Contents}

Foreword Page

1. Introduction _

1.1. Background

2. Experimental facilities and procedure

2.1. Chambers for preliminary program of 1940-1941 at the National Bureau of Standards............................. 2

a. Steel chamber $\ldots \ldots \ldots 2$

b. Vault

2.2. Beltsville vault $\ldots \ldots \ldots$

a. Film racks and containers

b. Load and ignition

c. Sprinklers

d. Detectors $\ldots \ldots \ldots$

e. Instrumentation

2.3. Experimental programs

3. Results _._.

3.1. Program of 1940-1941 at the National Bureau of Standards _-_ 9

3.2. Beltsville vault program with skeleton racks_____________ 11

3.3. Beltsville vault program with compartmented racks_______ 11

3.4. Supplementary film rack program _................. 14

4. Discussion $\ldots \ldots \ldots \ldots$

4.1. Pressure-load relationship _._.

4.2. Effect of film containers

4.3. Effect of film racks

4.4. Effect of sprinklers

4.5. Effectiveness of detectors and actuators

4.6. Summary

5. Conclusions

6. References

7. Appendix 


\title{
Fire Effects and Fire Control in Nitrocellulose Photographic-Film Storage
}

\author{
J. V. Ryan, J. W. Cummings, ${ }^{1}$ and A. C. Hutton ${ }^{2}$
}

\begin{abstract}
The results are given of a comprehensive research investigation conducted to determine the effects of variables such as film load, size and orientation of vent opening, volume of chamber, containers for rolls of film, rack types, and automatic-sprinkler systems on fires in nitrocellulose-film storage vaults, as indicated by internal pressure, temperature, fumes and flames, and extent of film damage. The data are tabulated and those from an earliex independent study are included for comparison. The effects of the variables are discussed and conclusions with respect to the maximum preservation of film are given.
\end{abstract}

\section{Introduction}

In some respects nitrocellulose is one of the most desirable photographic-film bases, especially for motion pictures. Until recently, when cellulose acetate "safet 5 " film came into common use, the vast majority of $35-\mathrm{mm}$ motion-picture film used was nitrocellulose. Unfortunately, although it is economical and has excellent photographic qualities, nitrocellulose is very easily ignited, is subject to self-heating and self-ignition [1], ${ }^{3}$ gives off toxic fumes during combustion, burns vigorously, and once well started, continues to burn on its own chemically combined oxygen even when submerged in a container of water [2, 3]. Also, this film goes through a process of decomposition that depends on time, temperature, and humidity. A study of this process has indicated that the danger of ignition by self-heating is almost nonexistent for new or well-preserved film but increases appreciably as the film becomes older and starts decomposition [1]. When this film is stored in large quantities, the danger of explosion is added to the hazards already mentioned. Although it is virtually impossible to obtain nitrocellulose film in this country at the present time, the large quantity of such film in storage still represents a hazard.

Standards for the storage of nitrocellulose film, based on experiments made in 1915, listed vault constructions without sufficient evidence that they are strong enough to withstand the internal pressures likely to be developed under the allowable load and vent conditions in case automaticsprinkler protection should be inoperative or have not been installed. Consequently in 1940 the National Bureau of Standards, at the request of the National Archives, undertook an investigation of factors that might be expected to affect the severity of and hazards from fires in nitrocellulose-film storage.

\footnotetext{
1 National Archives.

2 Formerly with NBS

${ }^{3}$ Figures in brackets indicate the literature references at the end of this paper.
}

As the preliminary prograin of the investigation, a series of experiments were made in two film chambers on the Bureau grounds in Washington, D. C. These experiments were designed to serve as a guide for the design of a vault more nearly the maximum size permitted by the standards, and of its instrumentation, by providing data on the pressures developed in confined spaces during fires involving greater amounts of film than had been used in most of the previous experiments. The vault was constructed near Beltsville, Md., and an experimental program set up to investigate the effects of such factors as film containers, racks, and sprinklers in addition to film load and venting. The over-all investigation was carried out to provide data essential for the preparation of recommended practices for safe storage of nitrocellulose film.

As many organizations had large amounts of nitrocellulose film in storage, an Inter-Agencr Advisory Committee on Nitrate Film Tault Tests was formed to plan the details of the remainder of the investigation. The committee was composed of representatives of interested Government and private organizations.

\subsection{Background}

Fires in those places wherein nitrocellulose film was present in quantity have been a problem since the introduction of this film. Sereral rery serious fires and explosions have occurred in storage centers [4]. In 1910 the U. S. Geological Survey made investigations on a small scale and. on the basis of their findings, recommenterl that not more than about $7 \mathrm{lb}$ of film be stored per square inch of vent area. In 1915 a special committee of the Committee on Explosives and Combustibles of the National Fire Protection Association published the results of experiments ente ducted on a larger seale [5]. Their timdings iscreed in general with those from the carlier experiments. but their recommendations ware for less-dense loading. These findings and reoommondations were used as the basis for standards that were accepted for many yours. Howrores experiented 
from actual fires indicated that pressures higher than those determined experimentally were being realized in storage fires. Therefore the National Bureau of Standards began the investigation reported herein during 1940 . The preliminary program was completed, but World War II made it necessary to postpone the large vault program until after the cessation of hostilities. Some time after the war it became possible to resume this investigation, and the previously mentioned committee was formed.

\section{Experimental Facilities and Procedure}

Two film chambers were used in the preliminary experiments at NBS in 1940-1941. One was of steel, and the other was a reinforced-concrete explosion chamber. The Beltsville vault was most representative of actual storage, having the form and being about one-half the size of many existing vaults. Details of the three chambers, their instrumentation, and of the experimental programs are given in the following sections.

\subsection{Chambers for Preliminary Program of 1940-1941 at the National Bureau of Standards}

One film chamber used in the preliminary program at NBS was a steel cylinder. The other was a reinforced-concrete chamber more nearly representative of actual storage facilities in that skeleton racks were installed and the film capacity was much greater than that of the steel cylinder.

\section{a. Steel Chamber}

The film chamber for 20 experiments in the $1940-$ 1941 program was a steel cylinder, inside diameter $2 \mathrm{ft}$, length $7 \mathrm{ft}$, with one end permanently sealed and the other end equipped to allow easy interchange of steel plates, in which were cut various size vents. The volume of the chamber was 22 $\mathrm{ft}^{3}$. It was provided with pressure taps to which were connected manometers. Two thermocouples were installed to obtain interior temperatures. They were of 18 gage chromel-alumel wires, with all but the junction and about $1 \mathrm{in}$. of the wires encased in asbestos sleeving. They were placed with the bare junctions on the longitudinal axis of the cylinder, one $2 \mathrm{ft} 4 \mathrm{in}$. from each end. The outside of the cylinder, including the sealed end, was insulated to prevent rapid heat loss. An ignition source was located about $1 \frac{1}{2} \mathrm{ft}$ outside the vent to ignite the combustible toxic fumes liberated. The film was in rolls, on and off reels, both in cans and uncontained. There was no rack in the chamber, but a steel frame was used to hold the film $7 \mathrm{in}$. from the vent opening. Except in experiment 12 , the film was ignited by means of an electrically heated wire placed in contact with film. In that instance a fire of scrap wood was built just outside the vent, and the film in the chamber was ignited by this "exposure fire." The details of the film load and vent area for each experiment are given in table 2 .

\section{b. Vault}

The other three experiments of the 1940-1941 program were made in a reinforced-concrete vault, the inner dimensions of which were 4 by 4 by $8 \mathrm{ft}$ (volume $128 \mathrm{ft}^{3}$ ). The walls were $24 \mathrm{in}$. thick. An opening was located in each end wall, one opening serving as the vent and the other as a loading entrance, the latter having been sealed during experiments. 'The vent area was varied by steel plates. Pressure taps and thermocouples were inchuded, which were connected to manometer's and potentiometers, respectively. The thermocouples were identical to those in the steel chamber except for placement and number. Four were placed along the center of the aisle, one each at:

(1) $19 \mathrm{in}$. from the vent end wall and $10 \mathrm{in.}$ above the floor;

(2) $38 \mathrm{in}$. from the vent end wall and $32 \mathrm{in}$. above the floor;

(3) 57 in. from the vent end wall and $10 \mathrm{in.}$ above the floor; and

(4) $76 \mathrm{in}$. from the vent end wall and $32 \mathrm{in.}$ above the floor.

The film was loaked on skeleton pipe racks in individual, one-reel cans and was ignited by an electrically heated wire.

\subsection{Beltsville Vault}

The reinforced-concrete vault, figure 1 , in which two experimental programs were conducted under the direction of the Inter-Agency Committee was in the form of a cubicle with a door at one end, an opening in the opposite wall, and an opening in the ceiling at the same end as the wall opening. 'The ceiling opening led to a vertical vent stack, which simulated the vent of the lower vault of a two-level building. The inner dimensions of the vault were $4 \mathrm{ft} 8 \mathrm{in}$. wide by $8 \mathrm{ft}$ deep by $10 \mathrm{ft}$ high. The vertical stack was an additional $14 \mathrm{ft} 10 \mathrm{in}$. high. The walls, floor, ceiling, and stack were of 10-in.-thick reinforced concrete. 'The door and coverings for each vent were of steel.

Both the vertical and horizontal vents were equipped with steel plates that could be adjusted to change the area of vent opening. An experimental cover of steel, weighing $256 \mathrm{lb}$, was laid over the 504-in. ${ }^{2}$ opening at the top of the vertical stack. It was held in place only by its weight. The vault door was hung to open inward and bear on the jamb on both sides, top, and bottom when closed. The vault was provided with pipes through the walls to permit the installation or connection of temperature- and pressure-measuring equipment, sprinkler systems, and fire and smoke detectors. 


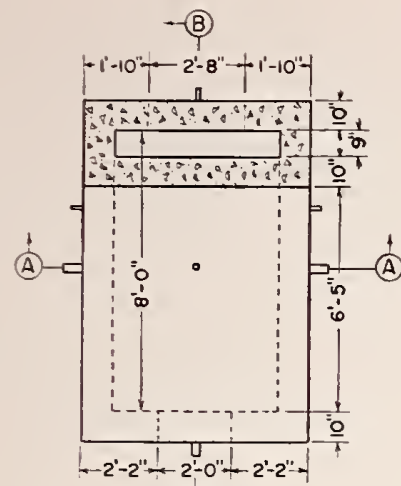

-(B)

ROOF PLAN

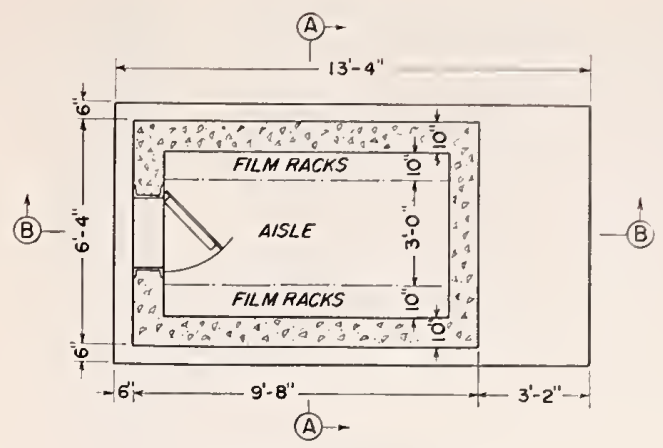

FLOOR \& FOUNDATION PLAN $\frac{1}{4} \times 2$ '-10 $\times 6^{\prime}-9$ "STEEL STACK COVER WITH $2 \times 2^{\prime \prime} \frac{1}{4}$ ANGLE FRAME

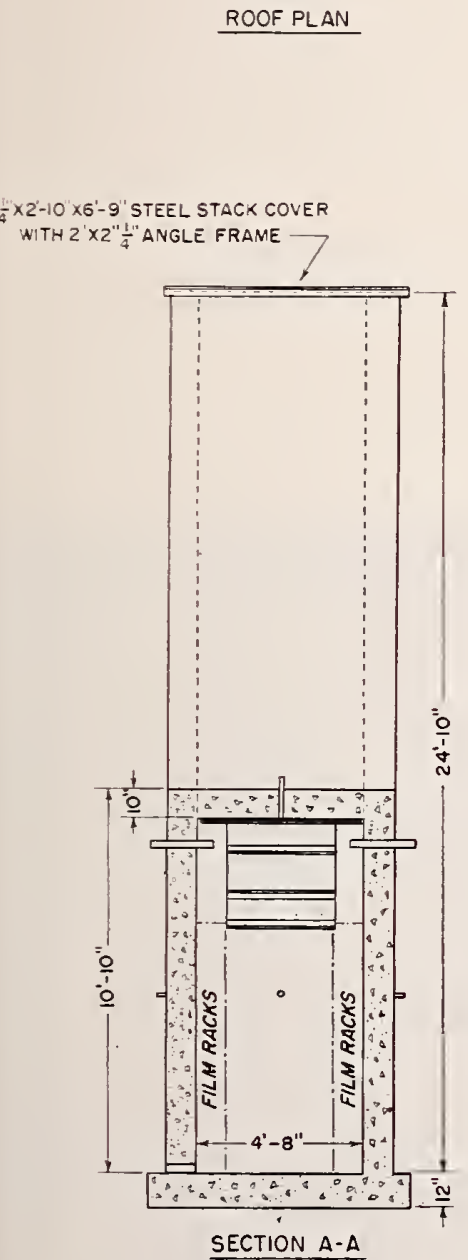

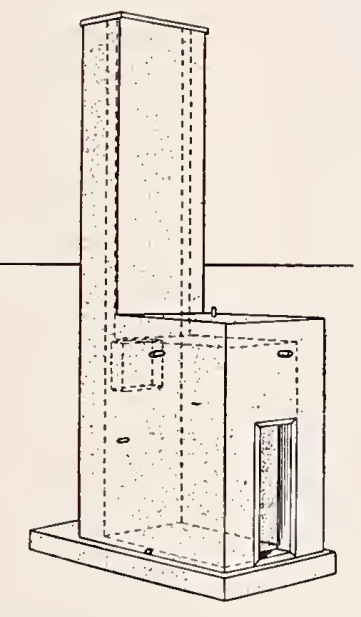

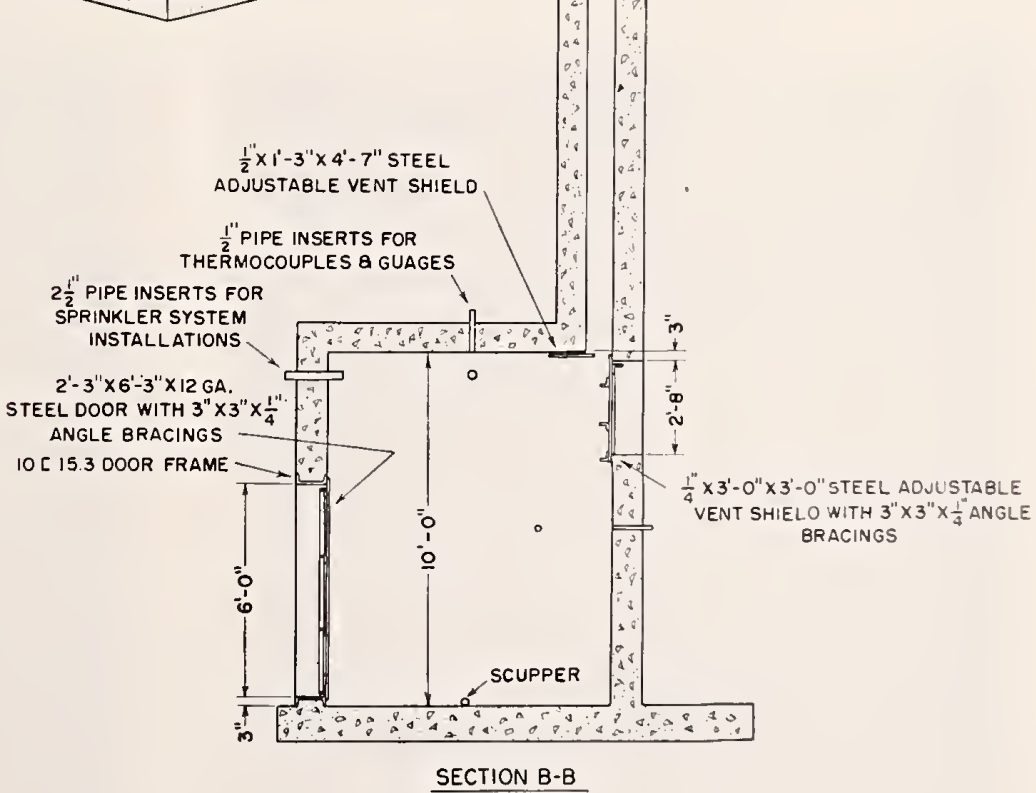

FIGURE 1. Construction details of $373-f t^{3}$ reinforced-concrete experimental film vault near. Biltsille, $M d$.

The vault volume of $373 \mathrm{ft}^{3}$ was about one-half the maximum allowed in generally accepted standards. Although the vault was not of maximum size, it was believed that the experimental results obtained therewith would be of the order of magnitude that might be obtained from experiments in a maximum-size vault. The vault was designed by members of the committee and built on the grounds of the U. S. Department of Aerientere Research Center at Beltsrille. Mel. on a locition selected to provide water supply. shop farilities. and isolation from inhabited places and valuable property.

\section{a. Filn Racks and Containers}

The film loads in these axperinents wore plated in various racks and types of combiners. The 
containers were either round or square metal cans, each of which held a single $1,000-\mathrm{ft}$ reel of $35-\mathrm{mm}$ film, or lined, multiple-reel shipping cases of a type approved by the Interstate Commerce Commission. Some of the latter cases held as many as 10 reels of film. The vertical-storage skeleton racks and horizontal-storage skeleton racks were of conventional design. The open-front compartmented shelf racks and the closed-front compartmented slielf racks were designed by members of the Inter-Agency Conmittee and incorporated features not a vailable in commercial racks.

The vertical-storage skelcton racks were simple arrangements of ordinary iron pipe attached to vertical steel frames, in which the film cans rested vertically on two horizontal pipes. Lateral support and restraint were provided for each film can by the adjacent cans in those instances in which the racks were loaded to maximum capacity. Gypsum board was used to separate adjacent rack end frames. These racks are shown in figure 2, with film cans in place. The horizontal-storage skelcton racks shown in figure 3 provided support to cach can by the partial shelves of the racks.

In three experiments $(4,5$, and 6$)$ the horizontalstorage racks were partially insulated by placing asbestos millboard or gypsum board in the three central stacks on cach side of the aisle to enclose each film can on all sides except toward the aisle,

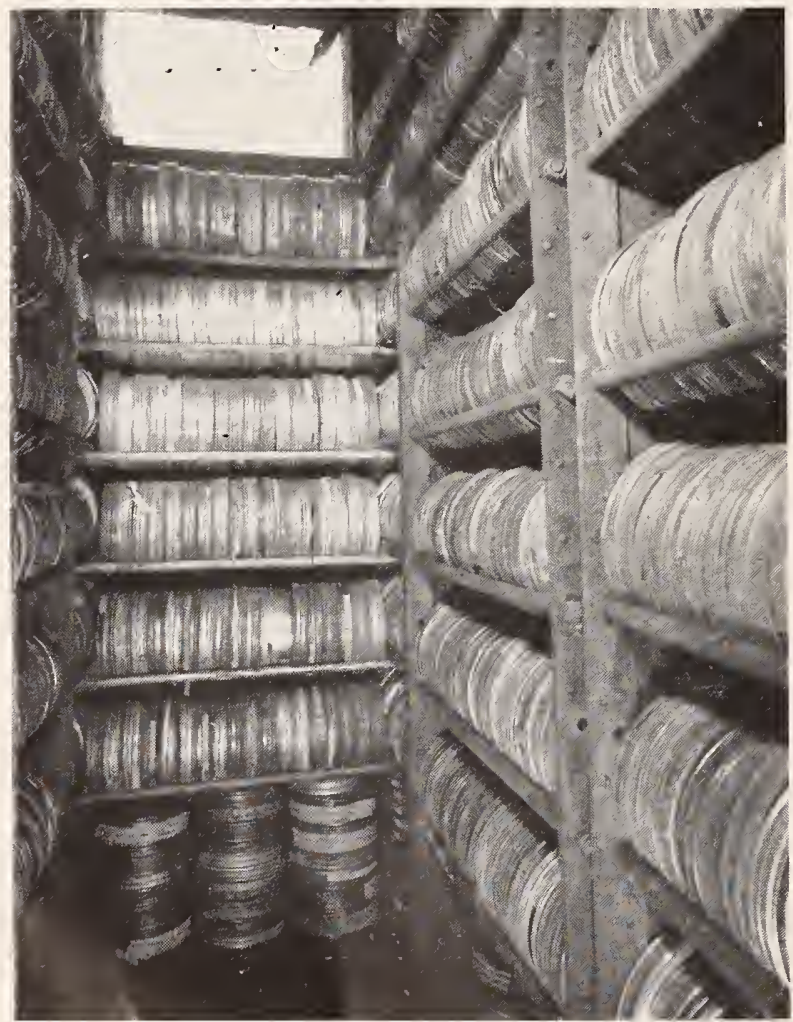

FIGURE 2. Fully loaded vertical-storage skeleton film racks in vaull.

The horizontal vent opening is at the top. as shown in figure 4. This was done to simulate compartmented racks and to determine what effect would be produced by isolating the igniter can from those adjacent to it.

Each open-front compartmented rack consisted of three vertical rows of compartments, 30 in a row, and stood 6 in. off the floor on sheet-metal legs. The over-all dimensions were $2 \mathrm{ft} 11 \frac{5}{8} \mathrm{in}$. wide by $6 \mathrm{ft} 11^{13 / 16} \mathrm{in}$. high by $11^{3 / 8} \mathrm{in}$. deep. They wcre constructed of light-gage sheet steel and insulated with $1 / 4-i n$. gypsum board applied to the undcrside of each shelf and the sides and rear of each compartment. The clear space of each compartment of the open-front rack was $11 \mathrm{in}$. wide by 11 in. deep by $2 \frac{1}{32}$ in. high. Each compartment was equipped with a film extractor, which consisted of a flexible steel strip attached to the left front corner, from where it curved around the rear of the compartment to the right front and passed through a guide. Pulling the loose end caused the ejection of the film can. The rack is shown in figure 5 .

Each closed-front compartmented rack consisted of three vertical rows of compartments, 26 in a row, and stood 6 in. off the floor on sheet-metal legs. The over-all dimensions were $3 \mathrm{ft} 11_{16}^{\prime} \mathrm{in}$. wide by $6 \mathrm{ft} 11^{1 / 4} \mathrm{in}$. high by $1 \mathrm{ft} \frac{1}{1 / 4} \mathrm{in}$. deep. They werc of the same general design as the open-front racks with the addition of an insulated door for

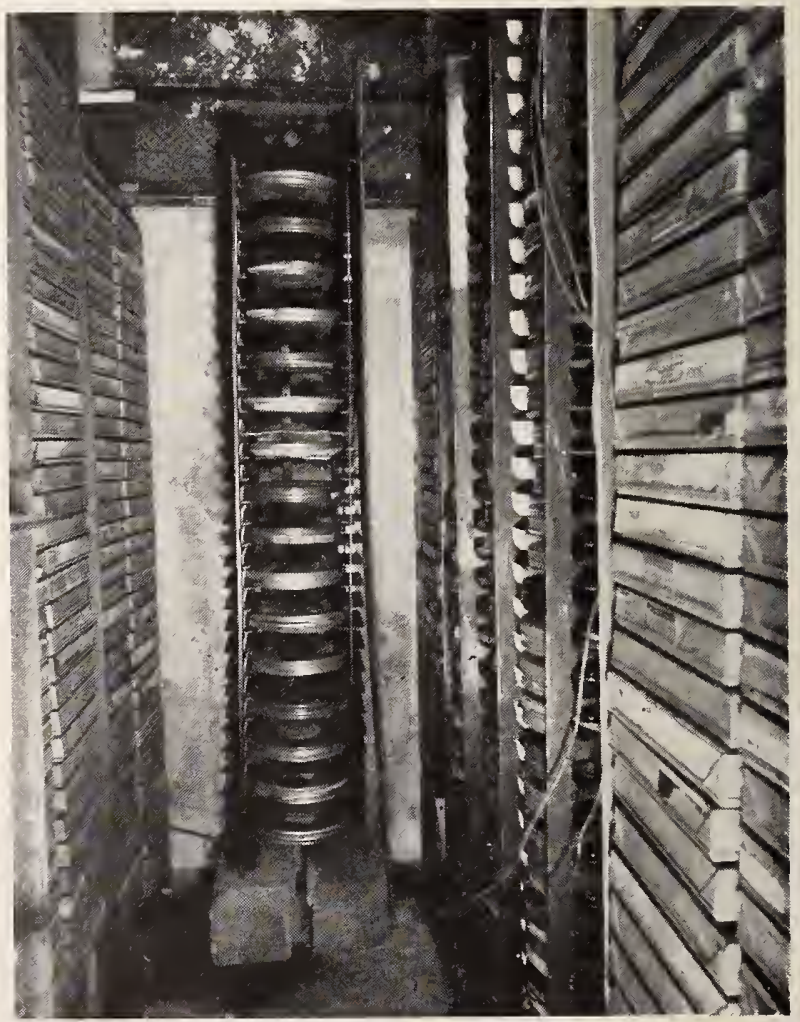

FIGURE 3. Loaded horizontal-storage skeleton film racks in vault, experiment 1. 
each compartment. The door was hung at the top from a piano-type hinge. The clear space of each compartment was $11 \frac{1}{2}$ in. wide by $11 \frac{1}{4} \mathrm{in}$. deep by 21/32 in. high. Each compartment was equipped with the same type of extractor as in the open-front rack. The rack is shown in figure 6 .

The skeleton racks were rlaced along each side and at the rear of the vault. For the largest loads, a shelf rack was placed above the vault door. The compartmented racks, open- or closed-front, were placed one on each side of the rault, there having been only two of each available. The type of rack for each experiment is included with the experimental log summary and in table 3.

\section{b. Load and Ignition}

For most of the rault experiments the film load was $5 \mathrm{lb}$ of film per square inch of vent area. In 1 experiment it was $6 \mathrm{lb} / \mathrm{in}^{2}{ }^{2}$ and in 4 others, $7 \mathrm{lb} / \mathrm{in} .{ }^{2}$. With full- to half-open vents, as used with skeleton racks, this corresponded to total film loads ranging from 2,520 to $4,970 \mathrm{lb}$ or loads per unit rolume of 6.8 to $13.3 \mathrm{lb} / \mathrm{ft}^{3}$. In compartmented racks, capacity loads of 780 and 900 lb were used with reduced vent areas. Information regarding the vent and load for each experiment is given in table 3 .

Ignition was achieved by a match in a coil of nichrome heater wire connected to a $12-\mathrm{v} d-\mathrm{c}$ source. The match and coil were placed inside a

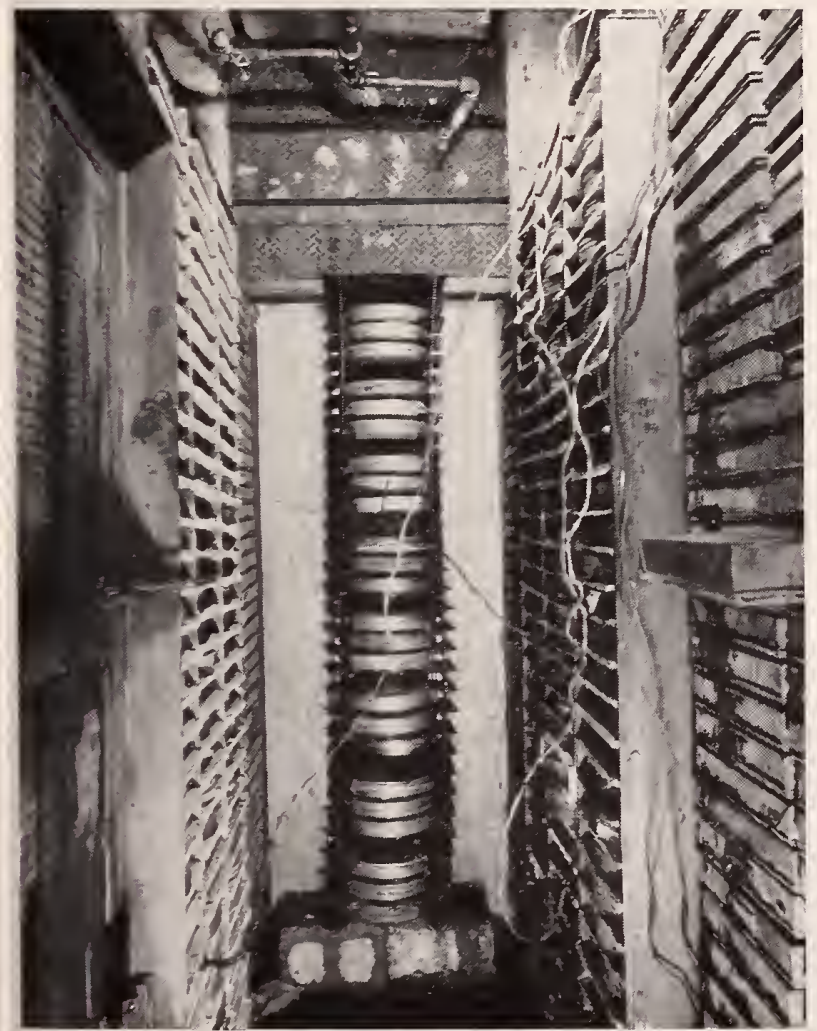

FIGURE 4. Compartmentation of horizontal-storage slieleton racks by means of insulation boards.

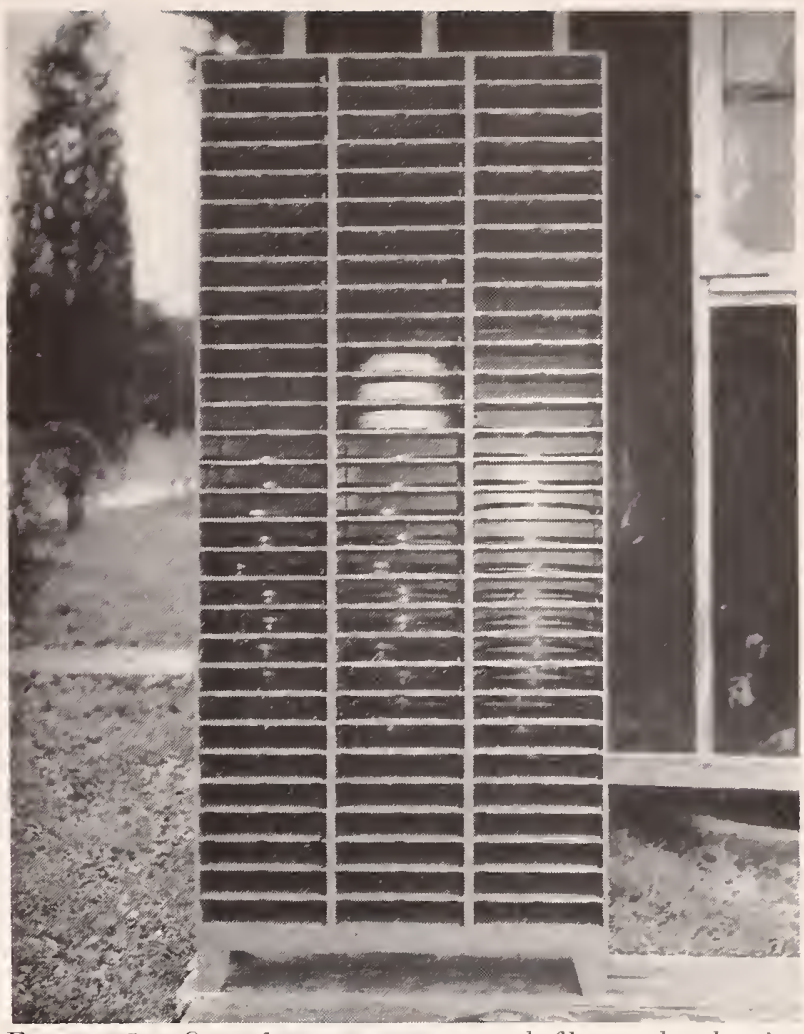

FIGURE 5. Open-front compartmented film rack, showing film extractors.

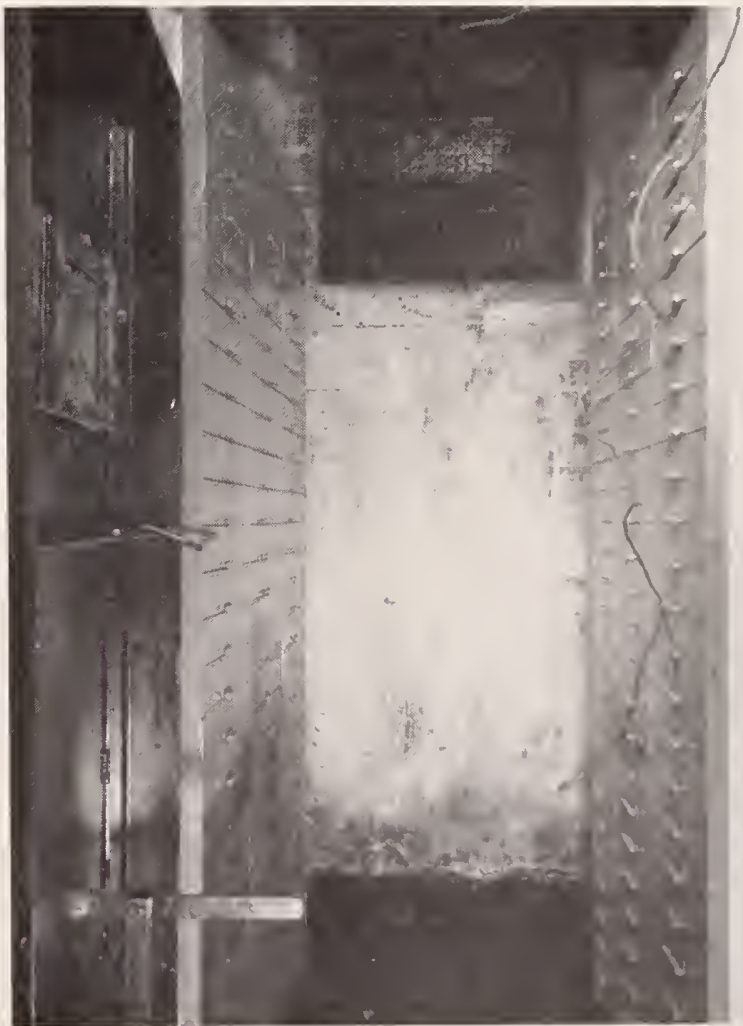

Figure 6. Closed-front compartmented film racks in raub. 
can of film, which is referred to as the "igniter can". The location of this igniter can was not the same in every test.

\section{c. Sprinklers}

Three tryes of sprinkler heads were employed; open spray heads, $165^{\circ} \mathrm{F}$ sprar heads, and $165^{\circ}$ F standard heads. Each installation of sprinklers consisted of six heads of the same type. The water-supply line, which entered the vault about $3 \mathrm{ft}$ above the door, fed two distinct pipe systems. These pipe srstems are shown in figure 7 , with open spray heads in place. The center pipe line with its six branches was used with the two types of spray heads to form directed spray sprinkler systems. The branches were directed so that the centerline of the water spray would strike the front of the racks at a level two-thirds of their height above the floor. The two side pipe lines, to each of which three sprinkler heads could be attached, were used with the standard heads to form a standard sprinkler system. When not to be used in a given experiment, the sprinklers of either or both systems were replaced by caps or plugs.

The open spray heads were used with the directed-spray system under "deluge" conditions in which discharge of all heads was actuated by a "deluge" valve located outside the rault in the supply line. Each head consisted of a hollow

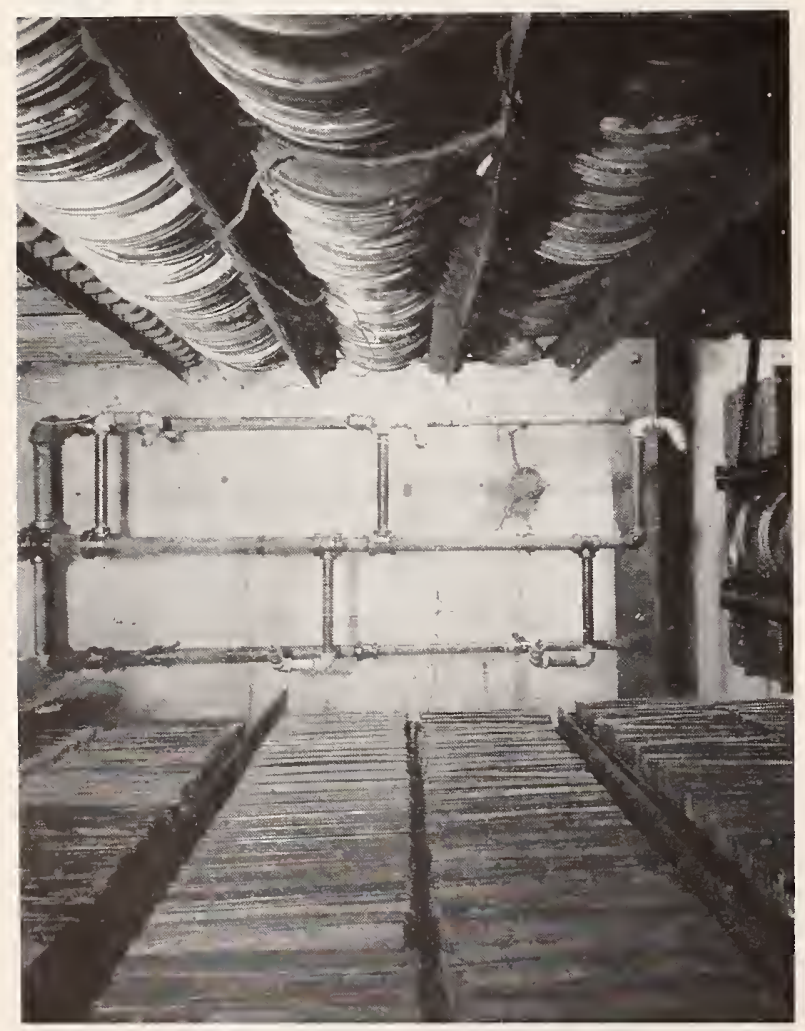

FIGURE 7. Pipes for overhead sprinkler systems, with open spray heads installed, experiment 3. bullet-shaped nozzle, inside of which was a fixed piece having a central venturi tube and three curved blades. The water entering the head was separated into two streams br the inner piece; a small central stream through the $1 / 8$-in. venturi where its speed was increased, and a larger annular stream through the fixed blades, which gave it a rotary motion. The central and annular' streams reunited as they entered the $5 / 16$-in. orifice, producing the spray enritted from the lread. Each head was designed to discharge $10 \mathrm{gpm}$ at a pressure of $15 \mathrm{lb} / \mathrm{in.}^{2}$ or $15 \mathrm{gpm}$ at $32 \mathrm{lb} / \mathrm{in.}^{2}$ pressure.

The $165^{\circ} \mathrm{F}$ spray heads were used with the directed-spray system under "wet-pipe" conditions. Each head was designed to discharge 10 gpm through a $5 / 16$-in. orifice to strike the outer surface of a conical deflector plate $1 \frac{11}{2}$ in. from the orifice, when operated at a flow pressure of 20 $\mathrm{lb} /$ in. $^{2}$. The conical deflector was perforated and deeply castellated along the outer edge to provide a directed spray of a uniform pattern. The discharge was actuated in the same manner as that from the $165^{\mathrm{C}} \mathrm{F}$ standard heads.

The $165^{\circ} \mathrm{F}$ standard heads were installed in vertical positions above the horizontal pipes. Each head was designed to discharge $15 \mathrm{gpm}$ vertically upward through a $1 / 2-\mathrm{in}$. orifice, when operated at a flow pressure of $7 \mathrm{lb} / \mathrm{in} .{ }^{2}$. The discharge was effectively seattered by a deflector plate $1 \frac{33}{4}$ in. above the orifice. These heads were used witlr a "wet-pipe" system, and the discharge was actuated by the melting of a fusible link at or near $165^{\circ} \mathrm{F}$, which released the cap sealing the orifice.

The water supply for the sprinklers came from a fire hydrant through either fire hose or 3-in. pipe laid on the ground to the base of the vault, thence up and across the face to the point where it entered the vault above the door. The deluge valve, which could be operated automatically by a detector or manually, was located in the rertical portion of the line about $5 \mathrm{ft}$ above the base of the vault. The water-flow control equipment, by which the desired rate of water flow could be set, was inserted in the line between the rault and the fire hỵdrant.

\section{d. Detectors}

Two rate-of-rise detectors were installed throughout the first 13 experiments and one of this type in 9 of the other 10 experiments. One detector element was mounted on the ceiling and was used to operate the deluge water valve. In those experiments in which the deluge valve was opened manually rather than automatically, or opened before the experiment began, the detector lighted an indicator light and the time of operation was noted. The second rate-of-rise detector, when used, was mounted near the door to simulate use with an automatic door-closing mechanism. The door closer was not installed, hence the detector signal went to another indicator light. 
In conjunction with the use of and for comparisons with the rate-of-rise detectors, each of two instruments designed to indicate the presence or amount of smoke were included in a few of the experiments. One smoke indicator was a detector designed to give an output signal only when the smoke reduced the transmission of light through a sample of the rault atmosphere by a given percentage. This detector was used to light an indicat or in two experiments; in one of which this was the sigmal for manual operation of the deluge valve and in both of which the times of operation were compared with those of a rate-of-rise detector. The other smoke indicator was a meter to measure the smoke densitr in terms of light transmission. It was used in the last three experiments, along with a rate-of-rise detector.

\section{e. Instrumentation}

Measurements were made of the pressures and temperatures inside the rault and of the water flow through the sprinklers. The times of operation of the detectors and sprinklers were observed. Pressures were measured at four taps in the rault, with each tap connected to a manometer and a gage or at a single tap connected to two manometers. In order to obtain measurements over a wide range of pressures, both water- and mercury-filled manometer's were emploved.

Temperatures were measured with 18-gage chromel-alumel thermocouples placed at various locations. One was $5 \mathrm{ft}$ from the front wall, $5 \mathrm{ft}$ from the floor and centered between the side walls; a second was 18 in. from rear wall, side wall, and roof; a third was $5 \mathrm{ft}$ from the front wall, $31 \mathrm{in}$. from the floor, and $12 \mathrm{in}$. from one side wall; and the fourth was at the same height and depth as the third but $12 \mathrm{in}$. from the opposite side wall. Each thermocouple junction and about 1 in. of the wires were bare with the remainder encased in asbestos sleeving. 'They were connected to self-balancing potentiometers calibrated to read directly in degrees centigrade. A panel of indicator lights was installed, one light for each automatic-sprinkler head, and one for each detector, including the detector that actuated the automatic operation of the deluge water valve. In view of the potential danger to human life from toxic gases, automatic motion picture cameras were set up to record the temperature and pressure data, as well as the times of operation shown by the indicator lights. The cameras, indicator's, manometers, potentiometers, and associated equipment were mounted in a truck trailer about $65 \mathrm{ft}$ from the vault. The fact that the tubes from the pressure taps to the manometers were of considerable length and that they were air-filled rather than liquid-filled undoubtedly affected the pressure indications. Such conditions would cause amplitude and time lags of undetermined magnitude between indicated and actual pressures during all fluctuations.

'The drop in water pressure at the flow-control equipment was a clear indication of the operation of the automatic-sprinkler heads, hence no indicator lights were used for this purpose in the last 10 experiments. Because the hazardous conditions anticipated had not developed in the first 1:3 experiments, cameras were not used to record data in the last 10 experiments, but were used for observations of the vault.

\subsection{Experimental Programs}

The investigation was composed of three experimental programs, the first of which consisted of the experiments in the $22-\mathrm{ft}^{3}$ steel chamber and the 128- $\mathrm{ft}^{3}$ vault on the grounds of the Bureau in 1940-1941. This first program was designed for the determination of maximum pressures, although observations were made of temperatures, combustion characteristics, and duration. The vents for the steel chamber were 3 by $3 \frac{1}{3}$ in. 4 by 5 in., and 5 by 8 in., giving vent areas of 10,20 , and 40 in. $^{2}$, respectively. The film load varied from 20 to $282 \mathrm{lb}$, giving load-to-rent ratios from 2.0 to $13.6 \mathrm{lb} / \mathrm{in}^{2}{ }^{2}$. The vents for the $128-\mathrm{ft}^{3}$ vault were $7 \frac{1}{2}$ by 8 in. and $15^{3 / 32}$ by $16^{3 / 16}$ in., giving areas of 60 and $244.3 \mathrm{in.}^{2}$, respectively. The loarls were 425 to $1,710 \mathrm{lb}$, to give load-to-vent ratios of 7.1 and $7.0 \mathrm{lb} / \mathrm{in}^{2}$. The specific information on vent, load, film containers, and some of the observed data are given in table 2.

The second program consisting of the first 13 experiments with skeleton racks in the Beltsville vault, was designed to study not only the pressure and combustion characteristics encountered in a large vault but, especially, the effect of various control measures on these characteristics and upon the amount of film destroyed or damaged. Variations were made in the following items: Type and size of vent, total film load, film containers and racks, use of thermal insulating material in the racks, type of sprinkler system, type of sprinkler heads, and water flow rate. The variations made in the first two items were designed to give the desired variations in the ratio of film load to vent area and in the ratio of film load to rault rolume. During and following each test, observations were made to determine: Pressures developed in rault. temperatures in the rault, fumo and thane characteristics, operation of detectors and sprinklers, and extent of film damage. The film louks ranged from 2,520 to $4,970 \mathrm{lb}$, the rent an reas from 360 to $720 \mathrm{in.}^{2}$, and the load-to-rent ratios from 5 to $7 \mathrm{lb} /$ in $^{2}$ approximately. I smmmary of the data for each experiment, including load. rack type, and other variables, is given in tablo: groups I through IV.

The third program, which consistod of the final 10 experiments in the Beltsville vilule dillored from the second proseram in that compantumented insulated film racks wore usod rather than the skcleton, or open, racks. The fim louse of eno() and $780 \mathrm{lb}$ for the open-front and elesed-front racks, respectirely, were limital hy the sizas of the racks and the number arailable. Howerere. 
the vent areas were reduced to keep the load-tovent ratio at $5 \mathrm{lb} / \mathrm{in}^{2}{ }^{2}$. The load and other data for each experiment are summarized in table 3 , groups V through VIII.

Following the completion of the third program, a supplementary program was made on the closed-front compartmented film racks for the purpose of determining the means by which ignition was established in cans of film adjacent to the igniter can. The actual compartments employed in these experiments had not been involved in previous fire damage.

\section{Results}

Brief descriptions of the results from each program and the supplementary experiments on the closed-front racks are given here. More detailed summaries of the experimental logs are given in the appendix. Most of the data and results have been condensed into tables. Table 1 , giving a summary of the 1915 experiments by the NFPA, is included here for comparison with the more recent results.

TABLE 1. Summary of data from NFPA experiments of $1915^{\mathrm{a}}$

Numbered experiments made in 3 -ft ${ }^{3}$ steel ehamber; "vault" experiment made in 133-ft ${ }^{3}$ masonry vault

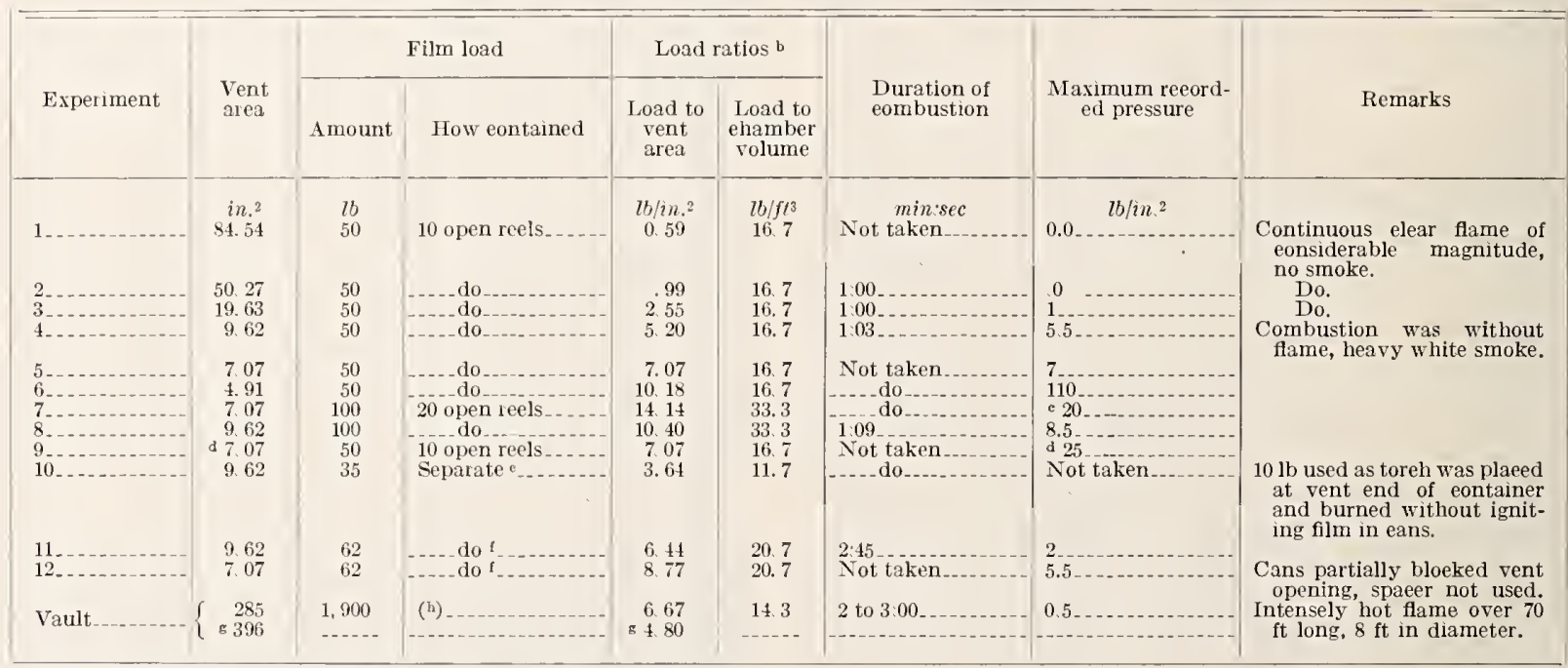

a This table based on a table and the text of referenee [5] at end of this paper.

b Not eontained in original table.

c Momentary pressure greater than $300 \mathrm{lb} / \mathrm{in}$ ?

d No. 12 wire sereen inside opening. Pressure dropped to 11 to $12 \mathrm{lb} / \mathrm{in}{ }^{2}$ after sereen was blown out.

e $25 \mathrm{lb}$ in eans, $10 \mathrm{lb}$ loose for toreh

i $50 \mathrm{lb}$ in eans, $12 \mathrm{lb}$ loose for toreh.

g Vent area inereased and load-to-vent ratio dropped when window sash blew out at about middle of experiment.

b $1,490 \mathrm{lb}$ in eans. $250 \mathrm{lb}$ on open reels, $160 \mathrm{lb}$ loose.

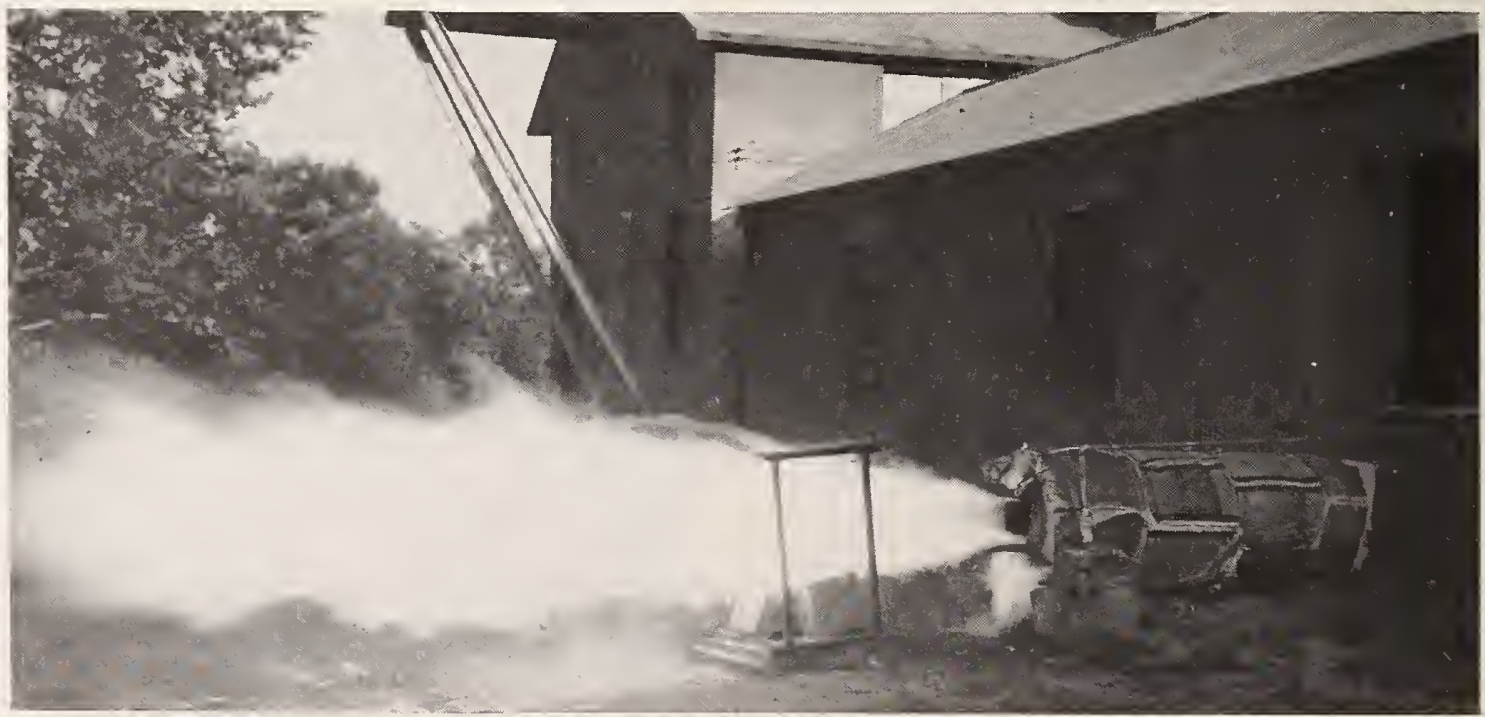

FIGURE 8. Discharge of gas and flames from $22-f t^{3}$ steel chamber during experiment 8 at National Bureau of Standards. 


\subsection{Program of $1940-1941$ at the National Bureau of Standards}

The features observed in each experiment of this program were similar in nature but not in magnitude to those observed in any other experiment of the program. This was true for the steelchamber experiments and the concrete-vault experiments. The only features that varied significantly from experiment to experiment were duration, intensity, and the recorded temperature and pressure maxima. Ignition of the igniter roll quickly resulted in the production or liberation of very large quantities of fumes that wore ignited. The rush of fumes and flames from the vent caused a loud roar and carried the flames many feet from the vent opening. Figures 8 and 9 show the steel chamber and concrete vault, respectively, during the experiments. Most of the data obtained in each test is given in table 2 .

TABLE 2. Summary of data from NBS film-fire experiments of 1940-1941

\begin{tabular}{|c|c|c|c|c|c|c|c|c|c|c|c|}
\hline \multirow{3}{*}{$\begin{array}{l}\text { Experi- } \\
\text { ment }\end{array}$} & \multirow{3}{*}{$\begin{array}{l}\text { Cham- } \\
\text { ber } \\
\text { Folume }\end{array}$} & \multicolumn{2}{|c|}{ Vent } & \multicolumn{5}{|c|}{ Film load } & \multicolumn{2}{|c|}{ Recorded maxima } & \multirow{3}{*}{$\begin{array}{l}\text { Approxi- } \\
\text { mate } \\
\text { duration } \\
\text { of com- } \\
\text { bustion }\end{array}$} \\
\hline & & \multirow{2}{*}{ Dimensions } & \multirow[b]{2}{*}{ Area } & \multicolumn{2}{|l|}{ Containers } & \multirow{2}{*}{$\begin{array}{c}\text { Weight } \\
\text { total }\end{array}$} & \multicolumn{2}{|c|}{ Load ratios } & \multirow[b]{2}{*}{ Pressure } & \multirow{2}{*}{$\begin{array}{l}\text { Temper- } \\
\text { ature }\end{array}$} & \\
\hline & & & & Type & Number & & $\begin{array}{l}\text { Load to } \\
\text { vent }\end{array}$ & $\begin{array}{l}\text { Load to } \\
\text { volume }\end{array}$ & & & \\
\hline $\begin{array}{l}1 \\
1 \mathrm{a} \\
2 \\
2 \mathrm{a} \\
3\end{array}$ & $\begin{array}{l}f t^{3} \\
22 \\
22 \\
22 \\
22 \\
22\end{array}$ & $\begin{array}{l}\text { in } \\
3 \times 31 / 3 \\
3 \times 31 / 3 \\
3 \times 31 / 3 \\
3 \times 31 / 3 \\
3 \times 31 / 3\end{array}$ & $\begin{array}{r}\text { in.2 } \\
10 \\
10 \\
10 \\
10 \\
10\end{array}$ & 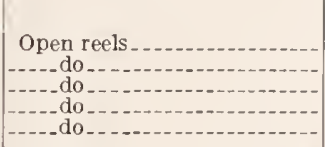 & $\begin{array}{r}4 \\
4 \\
10 \\
10 \\
14\end{array}$ & $\begin{array}{l}16 \\
20 \\
20 \\
48 \\
46 \\
68\end{array}$ & $\begin{array}{l}\text { Ib/in.2 } \\
2.0 \\
2.0 \\
4.8 \\
4.6 \\
6.8\end{array}$ & $\begin{array}{r}t b / f t^{3} \\
0.91 \\
.91 \\
2.18 \\
2.09 \\
3.09\end{array}$ & $\begin{array}{l}\text { lb/in. } .^{2} \\
0.7 \\
1.7 \\
2.4 \\
4.2\end{array}$ & $\begin{array}{r}{ }^{\circ} F \\
785 \\
945 \\
1,113 \\
1,304 \\
1,155\end{array}$ & $\begin{array}{l}\min : \sec \\
1: 25 \\
1: 22 \\
1: 22 \\
1: 20 \\
1: 35\end{array}$ \\
\hline $\begin{array}{l}4 \\
5 \\
6 \\
7 \\
8\end{array}$ & $\begin{array}{l}22 \\
22 \\
22 \\
22 \\
22\end{array}$ & $\begin{array}{l}3 \times 313 \\
4 \times 5 \\
4 \times 5 \\
4 \times 5 \\
5 \times 8\end{array}$ & $\begin{array}{r}10 \\
20 \\
20 \\
20 \\
\times 25\end{array}$ & Reels in cans ${ }^{-}$do do $_{1}$ & $\begin{array}{l}20 \\
20 \\
28 \\
28 \\
56\end{array}$ & $\begin{array}{l}100 \\
100 \\
140 \\
140 \\
280\end{array}$ & $\begin{array}{r}10.0 \\
5.0 \\
7.0 \\
7.0 \\
11.2\end{array}$ & $\begin{array}{r}4.55 \\
4.55 \\
6.36 \\
6.36 \\
12.72\end{array}$ & $\begin{array}{r}14.0 \\
1.8 \\
7.8 \\
2.2 \\
7.8\end{array}$ & $\begin{array}{l}1,325 \\
1,951 \\
1,325 \\
1,029 \\
1,240\end{array}$ & $\begin{array}{l}1: 30 \\
1: 33 \\
1: 25 \\
2: 20 \\
2: 08\end{array}$ \\
\hline $\begin{array}{r}9 \\
10 \\
11 \\
12 \\
16\end{array}$ & $\begin{array}{l}22 \\
22 \\
22 \\
22 \\
22\end{array}$ & $\begin{array}{l}4 \times 5 \\
4 \times 5 \\
4 \times 5 \\
4 \times 5 \\
5 \times 8\end{array}$ & $\begin{array}{l}20 \\
20 \\
20 \\
20 \\
37\end{array}$ & \begin{tabular}{|l} 
Cans, no reels. \\
- do $_{2}$
\end{tabular} & $\begin{array}{l}56 \\
28 \\
72 \\
28 \\
56\end{array}$ & $\begin{array}{l}271 \\
140 \\
140 \\
140 \\
280\end{array}$ & $\begin{array}{r}13.6 \\
7.0 \\
7.0 \\
7.0 \\
7.6\end{array}$ & $\begin{array}{r}12.31 \\
6.36 \\
6.36 \\
6.36 \\
12.72\end{array}$ & $\begin{array}{r}11.8 \\
2.9 \\
4.9 \\
4.9 \\
9.3\end{array}$ & $\begin{array}{l}1,410 \\
1,240 \\
1,586 \\
1,132 \\
2,187\end{array}$ & $\begin{array}{l}2: 30 \\
2: 05 \\
1: 30 \\
1: 20 \\
2: 05\end{array}$ \\
\hline $\begin{array}{l}17 \\
15 \\
19 \\
20 \\
21\end{array}$ & $\begin{array}{l}22 \\
22 \\
22 \\
22 \\
22\end{array}$ & $\begin{array}{l}5 \times 8 \\
5 \times 8 \\
5 \times 8 \\
5 \times 8 \\
4 \times 5\end{array}$ & $\begin{array}{l}40 \\
40 \\
40 \\
40 \\
20\end{array}$ & 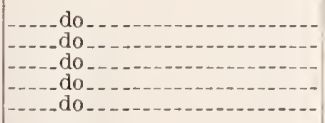 & $\begin{array}{l}61 \\
62 \\
53 \\
55 \\
47\end{array}$ & $\begin{array}{l}282 \\
280 \\
275 \\
280 \\
141\end{array}$ & $\begin{array}{l}7.0 \\
7.0 \\
6.9 \\
7.0 \\
7.0\end{array}$ & $\begin{array}{r}12.81 \\
12.72 \\
12.50 \\
12.72 \\
6.41\end{array}$ & $\begin{array}{r}11.5 \\
4.2 \\
3.0 \\
9.5 \\
2.3\end{array}$ & $\begin{array}{l}1,198 \\
1,113 \\
1,198 \\
1,494 \\
1,240\end{array}$ & $\begin{array}{l}1: 30 \\
2: 46 \\
2: 05 \\
2: 00 \\
3: 00\end{array}$ \\
\hline $\begin{array}{l}13 \\
14 \\
15\end{array}$ & $\begin{array}{l}128 \\
128 \\
128\end{array}$ & $\begin{array}{l}71 / 2 \times 8 \\
151 / 8 \times 161 / 4 \\
151 / 8 \times 161 / 4\end{array}$ & $\begin{array}{r}60 \\
\text { a } 188 \\
214\end{array}$ & $\begin{array}{l}-\ldots \text { do } \\
-\ldots \text { do }\end{array}$ & $\begin{array}{l}150 \\
335 \\
326\end{array}$ & $\begin{array}{r}425 \\
1,710 \\
1,686\end{array}$ & $\begin{array}{l}7.1 \\
9.1 \\
6.9\end{array}$ & $\begin{array}{r}3.32 \\
13.38 \\
13.18\end{array}$ & $\begin{array}{l}.93 \\
12.3 \\
12.4\end{array}$ & $\begin{array}{l}1,157 \\
1,859 \\
1,495\end{array}$ & $\begin{array}{l}3: 20 \\
2: 10 \\
1: 20\end{array}$ \\
\hline
\end{tabular}

s Rectangular rent partially blocked by film or cans; effective arca of opening rcduced thereby.

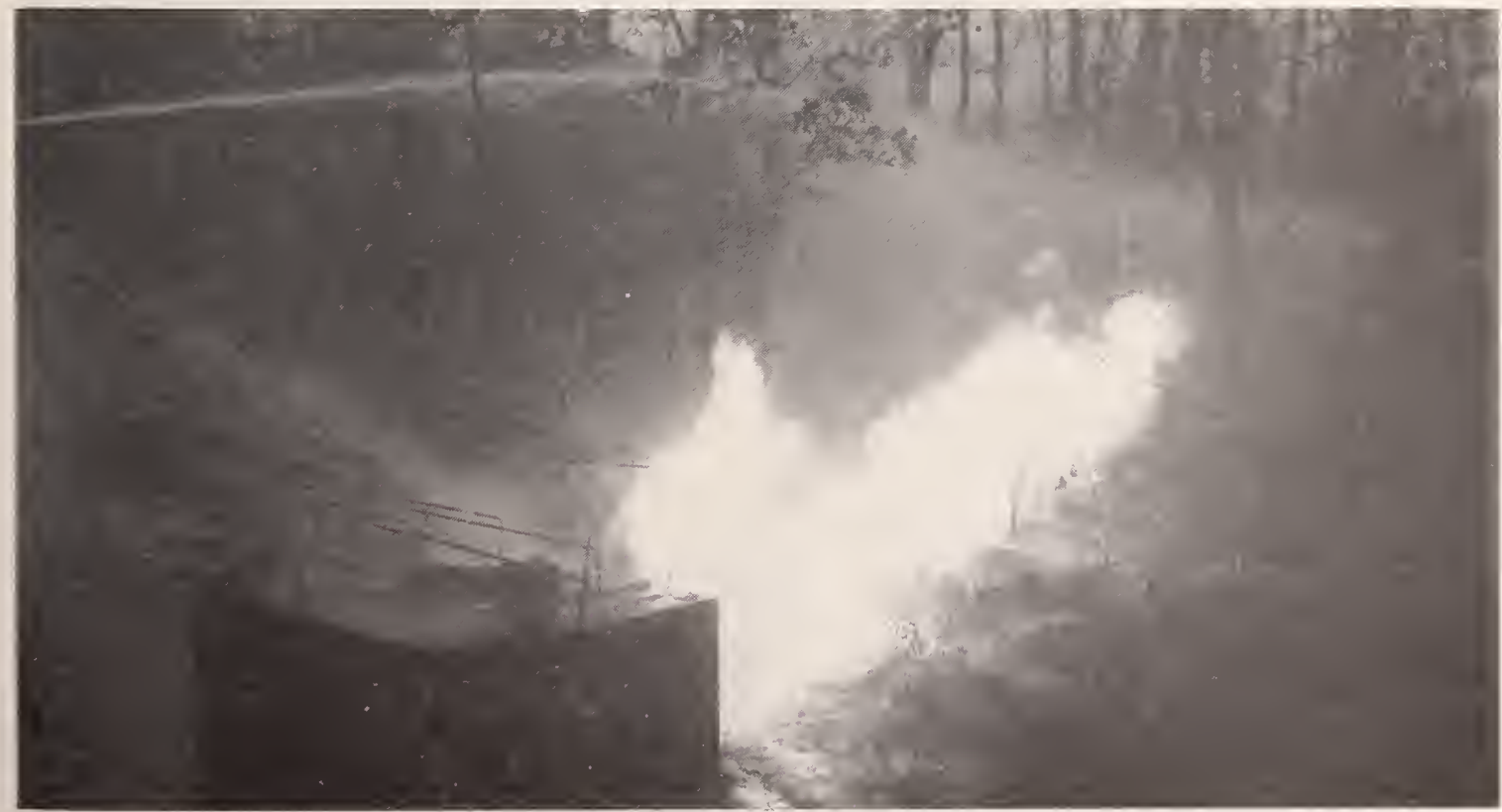

FIGURE 9. Discharge of gas and flames from 128-ft ${ }^{3}$ concrete chamber during cxpcriment 14 at . Vational liurcul of slandards. 


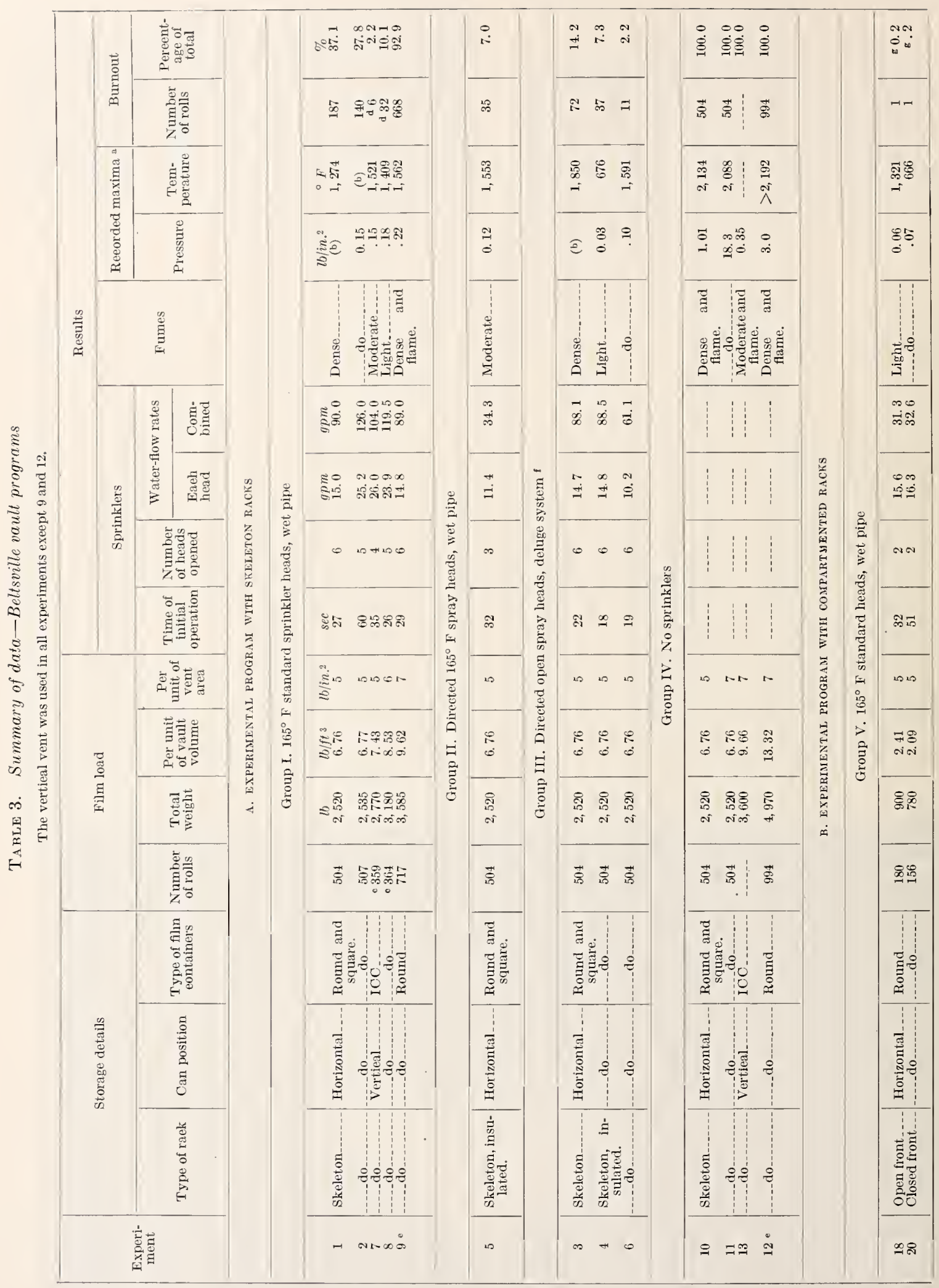




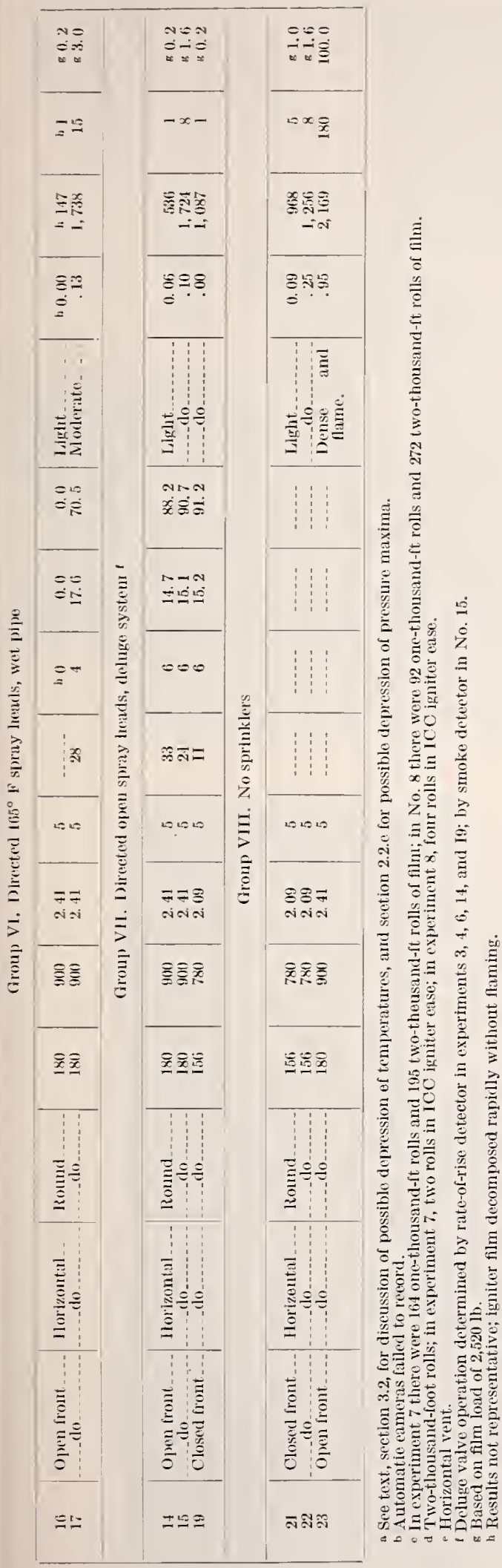

\subsection{Beltsville Vault Program With Skeleton Racks}

The features observed, as well as the temperature and pressure data, varied appreciably from experiment to experiment. Following ignition of the igniter roll, fumes were producerl and escaped from within the vault in clouds that ranged from light to very lieavy. In 5 (9 through 1.3) of the 13 experiments, only 1 (No.9) of which included sprinkler protection, the fumes became ignited outsicle the vault. In 1 of these 5 (No. 12) the flame lengths reached $100 \mathrm{ft}$ and film was thrown over $350 \mathrm{ft}$, both distances lıorizontally. Flames and ejected film from the vertical vent reached estimated lieights of 70 and $500 \mathrm{ft}$, respectively, in yet another (No. 11). The differences from experiment to experiment were brought about largely by the use of different types of sprinklers and regulation of the water-flow rate. No sprinklers were used in 4 of the experiments (10 through 13). Table 3 contains much of the data from the individual experiments, arranged in groups according to the type of sprinkler used. The data from this program are given in groups I through IV. The recorded temperature maxima may have been less than the true maxima due to the limited number of thermocouples and their locations in the vault as well as the possibility of wetting of thermocouple junctions in sprinkler discharges. However, the tabulated temperatures give an indication of the order of magnitude that might be expected. Discharges of dense fumes and flames from the vertical and horizontal rents are shown in figures 10 through 14 .

\subsection{Beltsville Vault Program with Compart- mented Racks}

The features observed in the individual experiments with compartmented racks varied somewhat from experiment to experiment. In only 1 of the 10 experiments were the fumes ignited. The fumes that escaped from the rault in the other 9 experiments were of light or moderate intensity. Table 3 contains much of the data from the individual experiments. The amount of film damaged was very low in all but one experiment, No. 23, in which open-front compartmented racks were employed without sprinkler protection. With the closed-front racks there was limited spread of iguition from compartment to compartment, but almost exclusively in a downwat direction from the igniter roll. 


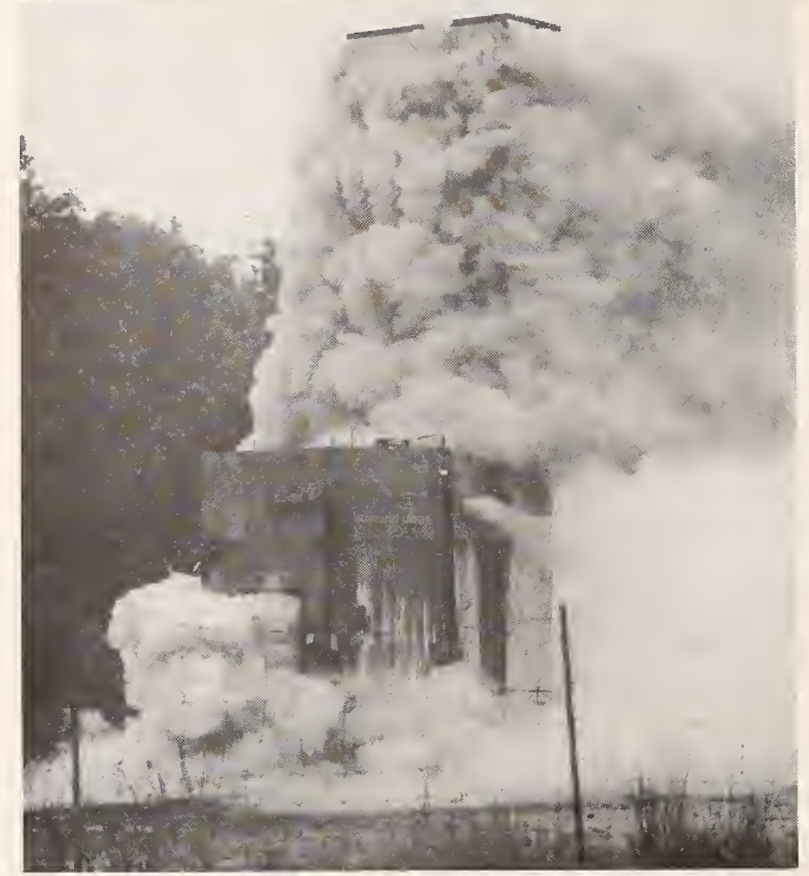

FiguRE 10. Discharge of dense fumes from Beltsville vault during experiment 2 , vent cover in place on vertical vent.

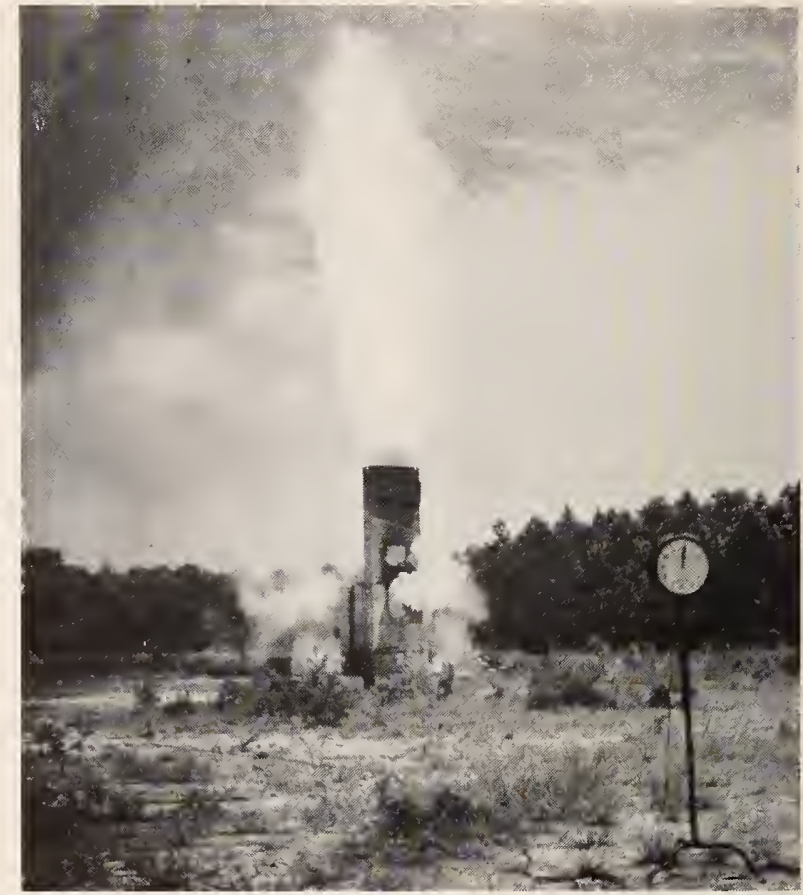

FIGURE 1. Discharge of flames about $60 \mathrm{ft}$ above vertical vent after vent cover blown off, experiment 11 in Beltsville vault.

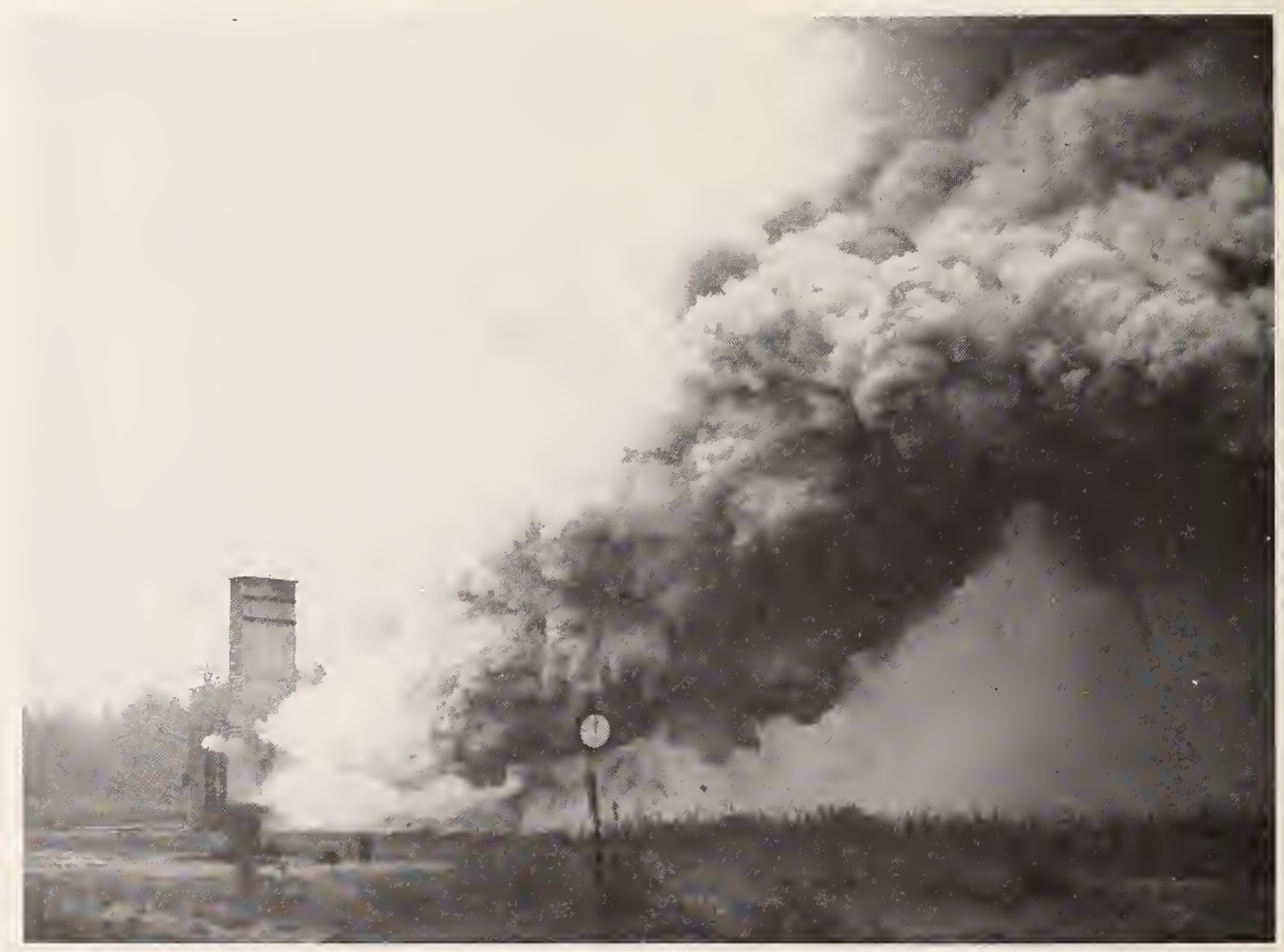

Figure 12. Discharge of very dense fumes from horizontal vent just as ignition of fumes initiated at vent, experiment 9. 


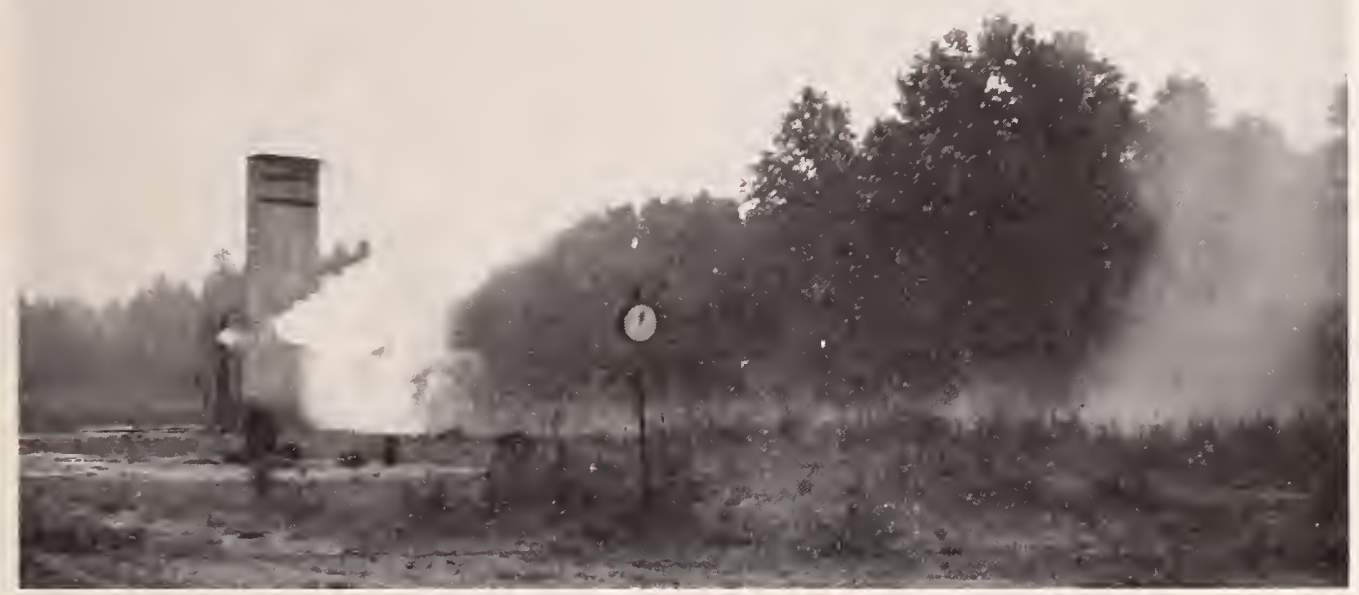

FIGURE 13. Appearance during experiment 9 about 10 sec after that in figure 11, showing that dense fumes were almost completely burned.

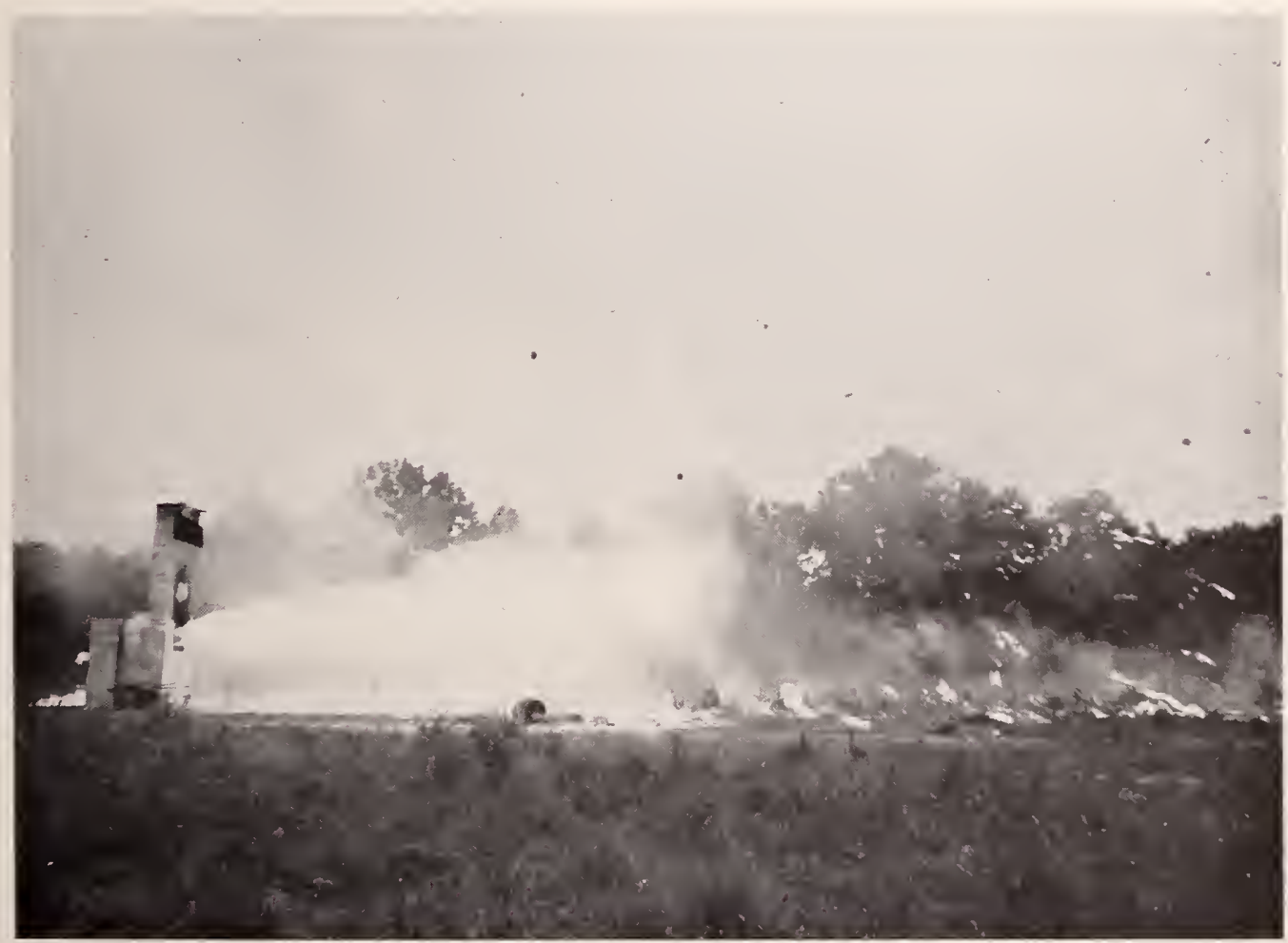

FISCRE 14. Tiolent discharge of flames, film cans, and film from horizontal vent during cxperiment 1? 


\subsection{Supplementary Film Rack Program}

The closed-front compartmented film racks had been designed with the intent that they should be capable of containing the fire damage to a single compartment-that of the igniter can-without the aid of sprinklers. However, they failed to do this (experiments 21 and 22), and several supplementary experiments were made in which these racks were set outside the vault so that the mechanics of the flame spread could be observed. A thermocouple junction was placed beneath the can in the compartment above the igniter and another on the top of the can below. As in the vault experiments, flame spread was in a downward direction. As the film in the igniter can burned, the door to the compartment below opened shightly, followed shortly by ignition of the film below. This chain of ignition (film above igniting that below) repeated several times and then stopped for no apparent reason. The temperatures measured on the cans below the igniters were consistently low which indicated that ignition of the other film was caused by some means other than heat transfer through the insulated shelves, probably by flame penetration from above.

\section{Discussion}

The storage of nitrocellulose-type film presents greater hazard than that of other films. The amount of film destroyed as the result of a nitrocellulose-film fire in a storage facility, the pressures developed, and the ensuing hazards to life and property are all dependent on the total amount of film in the vault or chamber, the ease with which ignition spreads, the size and type of the vent or vents, the density of loading, and the effectiveness of various fire-control devices employed.

\subsection{Pressure-Load Relationship}

The 1915 experiments by the NFPA, as reported by Stewart [5], led to the conchusion that the maximum loading density of film on bare reels that did not produce prohibitively dangerous pressure was approximately $7 \mathrm{lb} / \mathrm{in} .^{2}$ of vent, and to the recommendation that actual loadings be kept somewhat lower to be safe. Stewart gave a plot of part of his data and a curve through it but dicl not present a formula to express this curve. Various formulas have been suggested to express the relationship between pressure and film load.

Figure 15 is a plot of the data obtained from experiments with film on bare reels or loose film. It inchudes data from NBS experiments and Stewart's [5] experiments except two of the latter in which extreme pressures of short duration were

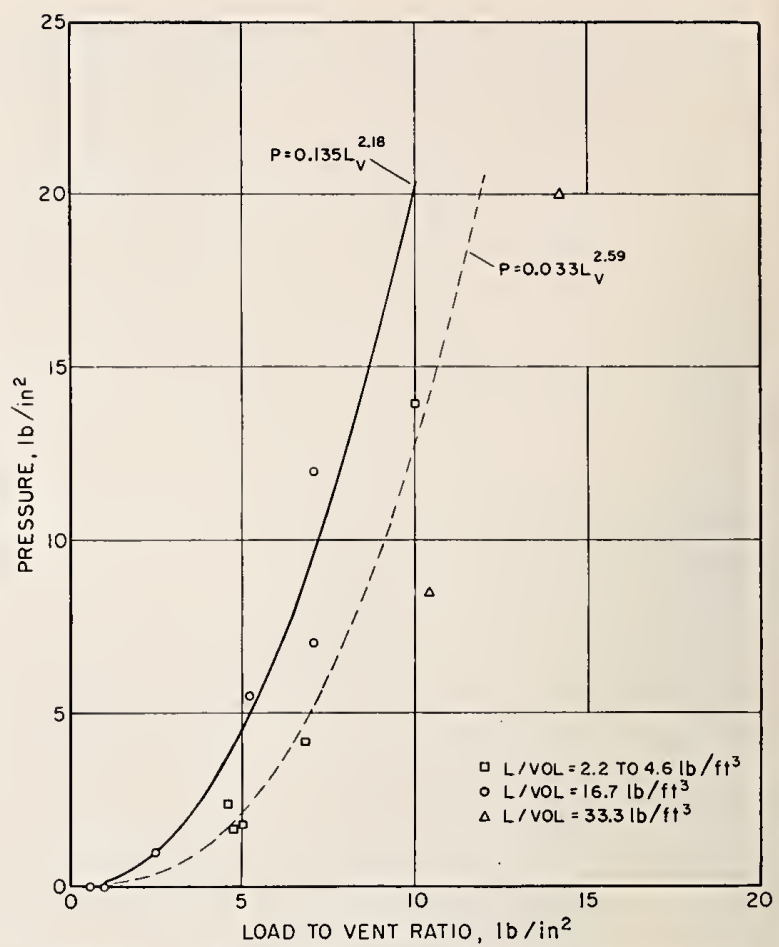

FIgURE 15. Pressure as function of load-to-vent ratio for film not in containers.

attributed to temporary reduction of vent area through partial obstruction by film. The curves were plotted from formulas derived by leastsquares analyses of the data. The solid curve represents the relationship

$$
P=0.135 L_{\mathrm{v}}{ }^{2.18}
$$

derived from data obtained with the load-tovolume ratio of $16.7 \mathrm{lb} / \mathrm{ft}^{3}$, indicated by the circles. The dashed curve represents the relationship

$$
P=0.033 L_{\mathrm{v}}{ }^{2.59}
$$

derived from data obtained with the load-to-volume ratio in the range 2.2 to $4.6 \mathrm{lb} / \mathrm{ft}^{3}$, indicated by squares. The triangles indicate data from two experiments in which the load-to-volume ratic was $33.3 \mathrm{lb} / \mathrm{ft}^{3}$. In each formula, $P$ is pressure in pounds per square inch, and $L_{\mathrm{v}}$ is load-to-ven ratio in pounds per square inch.

It should be borne in mind that the formulas and curves are intended to apply to only those cases in which the cellulose nitrate film is loos or on open reels, is stored without automati sprinklers or equivalent protection, and is $\mathrm{se}$ placed in the vault or chamber that the ven will not be even partially obstructed at any time The formulas do not include any extra margin o factor of safety. 


\subsection{Effect of Film Containers}

Two of the several factors that determine the peak pressure in a film rault during a fire are the rates at which the gaseous combustion products are generated and at which they escape from the chamber. The latter is related to the vent size and the former to the rate at which the film load burns. The individual reel, roll, or unit of film burns very rapidly. Howerer, the ease with which the ignition spreads from roll to roll will control the orer-all rate at which the film burns and gases are liberated. Reduction of this rate will produce a reduction in pressure within the chamber. Although none of the film cans and shipping cases used in these experiments prevented the erentual destruction of the film ther contained, ther did retard the spread of combustion and reduce the pressures observed. The experimental results of group I indicated that the ICC cases were somewhat superior to the metal cans, round or square.

\subsection{Effect of Film Racks}

The results obtained from the use of skeleton racks in various experiments without sprinklers appeared to indicate that the racks alone were not of significant value in reducing the extent or severity of the fire, or the gas pressure. However, these racks provided spaces between cans or groups of cans and a more uniform distribution of them throughout the vault than would be obtained br stacking the film can-on-can on the floor. Rack storage permits air circulation, which lessens the danger of self-heating and self-ignition in storage over extended periods of time.

With sprinklers the skeleton racks were effective in positioning the cans in a way that permitted the water to get to at least part of the exterior of each can. The horizontal-storage-type racks appeared to have been more effective because water was retained on the flat tops of the film containers.

The performance of the insulated open-front compartmented film racks when used with sprinklers was appreciably better than that of the skeleton racks with sprinklers. The pressures were of the same order of magnitude as those in the experiments with skeleton racks and sprinkler's, but the amount of film destroyed was significantly lower. When used without any sprinklers, the open-front compartmented racks failed to prevent the complete destruction of all the film.

The results obtained from experiments with the closed-front racks, although not fully satisfactory. were the most encouraging of all. In experinents 19 and 20 with sprinklers, only the ignitor cans were destroyed, and only 1 and 2 adjacent cans of film. respectively, were slightly damaged by heat.
These cans were eithor immediately above or below the igniter cans. The remainder of the film in the racks was not affected. In the experiments without sprinklers (No. 21 and 22), 5 and 8 cans of film were destroyed, respectively. In each instance the flame sprear was vertical only, there being no spread sidewise or across the aisle Except for one, all the cans in which film was destroyed were below the igniter can. "This singularity of direction of flame sprearl would indicate a single or relatively small number of defects in the design or manufacture of this type of film rack. The only routes through which flames could have passed from one compartment to another were the clearances between parts of the door hinge and thin gaps between the shelf and the rack walls which were observed in some compartments to have been in intimate contact only at the spotwelds by which they were joined. 'The preponderance of downward spread appeared due to deflection of flames in that direction by the partially open door and, possibly, by the lip of the film-can lid. The most logical explanation for the fact that the spread of ignition was stopped before reaching the bottom of the rack seems to be that a shelf was reached that fit tightly enough to prevent the penetration of sufficient flame to the compartment below to ignite the ean of film therein.

\subsection{Effect of Sprinklers}

With the skeleton racks, the amount of film destroyed when protected by directed-spray sprinklers was less than when protected by standard sprinklers in spite of the fact that the standard sprinklers used as much as twice the amount of water per head as the directed-spray heads. In 4 experiments ( 3 through 6 ) in which the former was used, the percentage of film destroyed ranged from 2.2 to 14.2 , average 7.7 . In 2 experiments ( 1 and 2 ) of the standard sprinklers with identical racks and cans, and essentially equal loads. the percentages were 27.8 and 37.1 . The high (92.9) percentage of film destrored in experiment 9. with sprinklers, appears to liave been attributable to other factor's, such as load density and (an position, rather than to the sprinklers. The sprinklers appeared to have been effective in preventing pressures as high as the $3.0 \mathrm{lb}$ in. observed in cxperiment 12 , without sprinklers, which w:1s very sinilar to 9 in other respects.

Although the film destruetion in experiments with sprinklers and skeleton racks wis not confined to the igniter can, neither wits it complete iu any such experiment. The rillege of pereentise destroyed was from 2.2 to 92.9 . 1 rertise 24.5 Howerer, in experiments without sprinkless, the burnout was less than total ouly with the chesedfront compartmented insulated film rateks. 


\subsection{Effectiveness of Detectors and Actuators}

The fusible-link sprinkler heads operated in as little as 26 sec after the eurrent was applied to the igniter. However, in 8 of the 10 experiments in which they were used, from one to all of the fusible links did not separate. The vault temperatures in one of these experiments did not exceed $150^{\circ} \mathrm{F}$ because the igniter roll did not flame but merely decomposed rapidly, without involving any other rolls. In the other experiments with fusible-link sprinklers, the maximum recorded temperatures ranged from $666^{\circ}$ to $1,738^{\circ} \mathrm{F}$ and yet some sprinklers did not operate. Factors that probably affected the behavior of the fusible links were (1) the local variations of temperatures within the vault, whieh in experiment 3 , with sprinklers, were observed to have been as great at $1,685 \mathrm{deg} F$ between thermocouples that were about $7 \mathrm{ft}$ apart and at different levels, and (2) the spray of water from operating sprinklers that may have fallen on and cooled the fusible elements of others not yet in operation. Also, this behavior may be attributed in part to the very short duration, often a few seconds, of the high temperatures. Although neither the mass nor the specifie heat of a fusible link was high, there would have been some short time required for transfer of suffieient lreat to the link to raise its temperature to the fusion point. There was no indication that the failure of any sprinkler to operate eould be attributed to defective materials or manufacture.

The temperature rate-of-rise detector's, in conjunetion with the deluge valve and open sprinklers, operated in from 18 to 33 sec and, in the experiments in which the detectors merely gave a signal for comparison with other deteetors, operated, or "alarmed", in from 10 to $45 \mathrm{sec}$, averaging $21 \mathrm{sec}$ for all experiments.

The smoke detector used in 2 experiments (14 and 15) gave signals at 20 and 23 see, respectively, and the smoke meter, which operated in 2 of the 3 experiments $(21,22$, and 23$)$ in which it was used, reached full scale (indicating a 50-percent loss of light transmission) at $14 \mathrm{sec}$ in eaeh instance. In the third experiment the intake was obstructed, thereby preventing fumes from entering.

The deluge valve was operated manually or by the rate-of-rise deteetor. It was observed that 4 sec elapsed between the deteetor signal and the start of water discharge from the sprinkler heads.

From the data of those experiments in which more than one type of detector or detectoractuator were used, the following eomparisons were obtained: (1) The period of time for the rateof-rise detector to operate was 36 to 78 pereent, average 66 , of that for the first fusible-link sprinkler to operate in the same experiment; (2) the period of time for the smoke detector to signal was 70 and 83 percent of that for the rate-of-rise detector in two experiments; (3) the period of time for the smoke meter to reach full-seale indieation was 64 and 93 percent of that for the rate-of-rise detector to signal.

\subsection{Summary}

The results obtained from the two programs in the Beltsville vault showed the desirability of sprinkler protection with the types of racks employed. With the skeleton racks the directedspray system appeared to be superior to the standard system. With sprinkler protection, the results obtained indieated the superiority of the compartmented insulated raeks over the skeleton racks. Of the compartmented raeks, the closedfiont type was better than the open-front type, specially in experiments without sprinkler protection (group VIII).

\section{Conclusions}

The conclusions are based not only upon the results of the experiments but also upon considerations of general safety and the protection of nearby property. Some of these are concerned with the protection and preservation of the film in a vault wherein a fire may start; the others with the prevention of fires or of their spread beyond the vault.

It was coneluded from the results obtained from a limited number of experiments in a vault of about one-half the maximum size allowed in generally accepted standards that:

1. Each vault for the storage of nitrocellulose film should be provided with a vent of sufficient area to prevent the development of dangerously high pressures during a fire.

2. With elosed-front compartmented racks and a film load of $5 \mathrm{lb} / \mathrm{in}^{2}$ of vent area, pressures as high as $0.25 \mathrm{lb} / \mathrm{in}^{2}{ }^{2}$ were observed. Vaults, including doors, should be designed for such pressure, when they are to be equipped with such racks.

3 . If open-front compartmented or skeleton film racks are employed and the film load kept at or below $5 \mathrm{lb} /$ in $^{2}$ of vent area, pressures as high as 1.0 $\mathrm{lb} /$ in. $^{2}$ may be developed during a fire, and the should be designed accordingly.

4. Temperatures observed were sufficiently high that only masonry or other equally noncombustible construetion should be used for film vaults.

5. The film should be stored in close-fitting metal cans, or containers giving equal protection, placed on racks within the vault.

6 . The film may be completely destroyed unless the vault is equipped with closed-front insulated eompartmented film raeks or adequate automaticsprinkler protection. The closed-front compartmented racks employed should be so constructed to prevent the spread of fire from one compartment to another. By adequate sprinkler protection is meant one sprinkler head, preferably of the directed-spray type, for each $60 \mathrm{ft}^{3}$ of vault.

7. The minimum destruction of film was obtained by the use of closed-front compartmented racks and automatie sprinklers of the direetedspray type. 
It was further concluded from the data and from considerations of safety and protection of property that:

$S$. The film in a vault or group of vaults represents a hazard to the surroundings so that vaults should be located where ther may be expected to remain isolated from raluable property.

9. The raults used should be equipped with rertical rents or means to deflect the discharge in a rertical direction. The minimum dimension of the rent should be greater than the maximum dimension of the film containers to be stored. The throat edges of the rent should be beveled or funneled at approximately a $45^{\circ}$ angle to prevent film containers sticking in and partially reducing the rent opening.

10. Any cover on the vent should be so designed and constructed that it will open before the internal pressure rises to $0.25 \mathrm{lb} / \mathrm{in}^{2}$.

11. Any device such as electric or heating equipment that might ignite film should be placed and enclosed in such a manner that contact with film is not possible.

\section{References}

[1] J. W. Cummings, A. C. Hutton, and H. Silfin, Spontaneous ignition of decomposing cellulose nitrate film, J. Soc. Motion (Picture and Television Engrs. 54, No. 3 (March 1950).

[2] R. A. Mitchell, The 35-mm projection positive film, Intern. Projectionist XXV, No. 2 (Feb. 1950).

[3] D. W. Wood, Celluloid dangers with some suggestions, Red Books of British Fire Prevention CommitteeNo. 179 (1913).

[4] For film storage fire, NFPA Quart. 31, No. 2 (Oct. 1937 )

[5] F. J. T. Stewart, Fire tests of nitrocellulose motion picture films, NFPA Quart 9, No. 1 (July 1915).

[6] Standards of the National Board of Fire Underwriters for storage and handling of nitrocellulose motion picture film, NBFU Pamphlet No. 40.

\section{Appendix. Observation Details}

The logs of observations made during and after each experiment are summarized. Where the observed behaviors within a program were similar, and the number and range of variables were limited, the logs are combined into a general description.

\subsection{Program of 1940-1941 at the National Bureau of Standards}

The features observed in all the steel-chamber experiments were similar, differing only in degree and elapsed time. The first flames or fumes were observed about 10 sec after the ignitcr current was turned on. The discharge of flames and fumes, which indicated rapid combustion, continued for periods of from 80 to 200 sec and reached its peak at from 40 to $105 \mathrm{sec}$. The discharge was marked by flames that reached lengths of 20 to $80 \mathrm{ft}$ (fig. 7), a loud roar, and occasional blasts, the latter apparently caused by explosions of individual film cans or variations in pressure resulting from temporary obstructions of the vents. The rush of gases was so rapirl in some instances that the flames were extinguished. The maximum recorded temperatures in the cliamber ranged from about $785^{\circ}$ to $2,190^{\circ} \mathrm{F}$, and the maximum recorded pressures ranged from 0.7 to $14.0 \mathrm{lb} / \mathrm{in} .^{2}$. In experiment 11 , the lid of a film can was blown through the vent. In experiment 12 , with ignition from a fire outside the rent, the first flames from within the chamber were observed at $9 \mathrm{~min} 30 \mathrm{sec}$, but the bchavior thereafter followed the above pattern.

The features observed in the $128-\mathrm{ft}^{3}$ vault experiments werc similar to those in the steelchamber experiments but of greater magnitude in some respects. The first flames issued from the vent about $16 \mathrm{sec}$ after ignition. The discharge reached its peak at about $60 \mathrm{sec}$ and had a duration of about $130 \mathrm{sec}$. The flames reached lengths of 50 to $100 \mathrm{ft}$ or more (fig. 8), and film and cans were blown out the vents to distances up to $300 \mathrm{ft}$. An estimated $100 \mathrm{lb}$ of film was blown out in expcriment 14 . In experiment 15 , a tree $50 \mathrm{ft}$ from the vent and several feet from the center of the flame path was scorched from the ground up to a height of about $22 \mathrm{ft}$. The maximum recorded temperatures were $1,160^{\circ}$ to $1,860^{\circ} \mathrm{F}$, and the maximum recorded pressures were from 0.93 to $12.4 \mathrm{lb} / \mathrm{in}^{2}$.

In 2 of the steel-chamber experiments, 8 and 16 , and 1 of the concrete-vault experiments, No. 14, the vents were partially obstructed by film or film cans. This resulted in lower vent areas and higher load-to-vent ratios than planned for the particular experiments.

\subsection{Beltsville Vault Program with Skeleton Racks}

Because of the increased number of variables introduced in these expcriments, as compared with those at NBS in 1940-1941, the results of each experiment are summarized individually. Ther are not given in numerical order, but are grouped by related items among the variables. The reltical vent was used in all experiments except 9 and 12 , as noted.

Group $I$. The following are summaries of results of the experiments in which six $165^{\circ} \mathrm{F}$ standard sprinkler heads were employed:

Experiment 1. Loaded in horizontal-storage skeleton racks to provide load-to-rent ratio of $5 \mathrm{lb} / \mathrm{in.}$." Water flow set for $15 \mathrm{gpm}$ per head. At 20 sec, rate-of-rise indications for simulated door-trip and deluge-valve operations; ?7 sec, first sprinkler operated; 45 see, blast inside viult; 50 sec, fumes from vent; 1 min 55 see, dense brown fumes from vent, cover was lifted periodically (indicating pressure of about $0.1 \mathrm{lb} / \mathrm{in} .^{2}$ ), relieving pressure; 4 min, funes diminished; 10 min, witer turned oft.

Actual water flow 15.0 gpm per head, six operated. Apparent duration of combustion 7 min. Automatic camera failed to record pressures but visusl observation of about $0.2 \mathrm{lb} / \mathrm{in.}{ }^{2}$ noted. Miximum recorded compersture $1,274^{\circ} \mathrm{F}\left(690^{\circ} \mathrm{C}\right)$. Only one-third as many cans of tilm burned out in rack containing igniter can is in opposite rack. 
Experiment 2. Loaded in horizontal-storage skeleton racks to provide load-to-vent ratio of $5 \mathrm{lb} / \mathrm{in} .^{2}$, water flow set for $22.5 \mathrm{gpm}$ per head. At $20 \mathrm{sec}$, first fumes; $45 \mathrm{sec}$, rate-of-rise indication and light blast; $46 \mathrm{sec}$, door-trip signal received; $1 \mathrm{~min}$, first sprinkler operated; 4 min 30 sec, very dense fumes; $7 \mathrm{~min}$, fumes nearly ceased; $10 \mathrm{~min}$, water off. Water valve reopened at $10 \mathrm{~min} 22 \mathrm{sec}$, shut finally at $15 \mathrm{~min} 30 \mathrm{sec}$.

Actual water flow 25.2 gpm per head, five heads operated. Apparent duration of combustion $7 \mathrm{~min}$, maximum recorded pressure $0.15 \mathrm{lb} / \mathrm{in}^{2}{ }^{2}$. Only about half as many cans of film burned out in rack containing the igniter can as in opposite rack. The discharge of fumes, shown in figure 9 , was very dense.

Experiment $\%$. Loaded in vertical-storage skeleton pipe racks to provide load-to-vent ratio of $5 \mathrm{lb} / \mathrm{in}^{2}{ }^{2}$ with $1,000-$ and $2,000-\mathrm{ft}$ reels in ICC cases, water flow set for $20 \mathrm{gpm}$ per head. At $23 \mathrm{sec}$, first fumes; $25 \mathrm{sec}$, deluge valve operated, door-trip signal received; 35 sec, sprinklers operated; $45 \mathrm{sec}$, dense fumes from vent; 2 min $30 \mathrm{sec}$, all fumes ceased; $10 \mathrm{~min}$, water off.

Actual water flow rate $26.0 \mathrm{gpm}$ per head, four heads operated. Apparent duration of combustion 2 min. Maximum recorded pressure $0.15 \mathrm{lb} / \mathrm{in} .^{2}$. On the average, the fumes were of moderate density. The only films burned out other than those in the ICC case containing the igniter can were in two cases in the opposite rack and below the level of the igniter can. Maximum recorded temperature about $1,521^{\circ} \mathrm{F}\left(827^{\circ} \mathrm{C}\right)$

Experiment 8. Loaded in vertical-storage skeleton pipe racks to provide load-to-vent ratio of $6 \mathrm{lb} / \mathrm{in} .^{2}$ with 1,000 and 2,000-ft reels in ICC cases, water flow set for $20 \mathrm{gpm}$ per head. At 19 sec, first fumes; $21 \mathrm{sec}$, deluge valve operated, door-trip signal received; 26 sec, sprinklers operated; 35 see, voluminous dense fumes from vent; 2 min 10 sec, fumes ceased; $10 \mathrm{~min}$, water off; $12 \mathrm{~min} 20$ sec, water back on; off again at 14 min 10 sec.

Actual water flow 23.9 gpm per head, five operated. Apparent duration of combustion 2 min. Maximum recorded pressure $0.18 \mathrm{lb} / \mathrm{in}^{2}{ }^{2}$. On the average, the fumes were light. Flame and some film came out the vault scupper early in the test. Maximum recorded temperature $1,409^{\circ} \mathrm{F}\left(765^{\circ} \mathrm{C}\right)$. Approximately 15 percent of the film that burned out, including the igniter film, was in the rack containing the igniter can.

Experiment 9. Loaded in vertical-storage skeleton pipe racks to provide load-to-vent ratio of $7 \mathrm{lb} / \mathrm{in} .^{2}$, horizontal vent, water flow set for $15 \mathrm{gpm}$ per head. First fumes, door-trip signal and deluge-valve signal received all at 23 sec; sprinklers operated at $29 \mathrm{sec} ; 40 \mathrm{sec}$, dense fumes from vent; 48 sec, more sprinkler heads opened; $1 \mathrm{~min} 30 \mathrm{sec}$, film ash from vent with fumes; 2 min 15 sec, fumes ignited; $2 \mathrm{~min} 30 \mathrm{sec}$, flame length $50 \mathrm{ft} ; 3 \mathrm{~min} 30 \mathrm{sec}$, flames licking up back of vault stack; $6 \mathrm{~min}, 10 \mathrm{ft}$ flames; $10 \mathrm{~min}, 15 \mathrm{ft}$ flames; $14 \mathrm{~min}$, area of concrete about 3 - $\mathrm{ft}$ diameter on back of vault stack spalled; $16 \mathrm{~min} 30 \mathrm{sec}$, water supply increased to maximum rate; $38 \mathrm{~min}$, water flow reduced to initial rate.

Actual water flow $14.8 \mathrm{gpm}$ per head, until increased to $24.3 \mathrm{gpm}$ per head at $16 \mathrm{~min} 30 \mathrm{sec}$, six heads operated. All but about 7 percent of the film was burned out. Nearly all of the unburned film was in the bottom racks on the side opposite the igniter can. The firt could not be controlled by the initial water flow and only after several minutes, if at all, by the maximum flow obtainable. However, the duration of combustion indicated that the sprinklers retarded the rate of combustion. The maximum recorded temperature and pressure were $1,562^{\circ} \mathrm{F}\left(850^{\circ} \mathrm{C}\right)$ and 0.22 lb/in. ${ }^{2}$, respectively. Figure 11 shows the cloud of fumes just as their ignition started at the vent.

Group II. The following is a summary of the experiment in which six $165^{\circ} \mathrm{F}$ spray-type sprinkler heads were used in a directed-spray system. The vertical vent was employed.

Experiment 5. Loaded in horizontal-storage skeleton racks to provide load-to-vent ratio of $5 \mathrm{lb} / \mathrm{in} .^{2}$, water flow set for $10 \mathrm{gpm}$ per head. Gypsum board or asbestos mill- board was used to insulate top, bottom, rear, and each side of each can in the central three sections of racks on each side. At 15 sec, first fumes; 20 sec, deluge-valve operation simulated; 21 sec, door-trip signal received; 32 sec, first sprinkler operated; 3 min 9 sec, fumes ceased; $10 \mathrm{~min}$, water off; $11 \mathrm{~min}$, on again; off at $15 \mathrm{~min} 30 \mathrm{sec}$

Actual water flow $11.4 \mathrm{gpm}$ per head, three operated. Apparent duration of combustion $3 \mathrm{~min}$. Maximum recorded pressure $0.12 \mathrm{lb} /$ in. $^{2}$. Fumes were heavy during first $3 \mathrm{~min}$ but average only moderate. Maximum recorded temperature $1,553^{\circ} \mathrm{F}\left(845^{\circ} \mathrm{C}\right)$. The can immediately opposite to the igniter can was left partly open with a loose end of film outside, which served as a secondary igniter. The amount of film burned out adjacent to this secondary igniter was nearly twice that adjacent to the primary igniter. One-fifth of the total amount burned out was in an end rack.

Group III. The data in this group are from those experiments in which six open-spray sprinkler heads were used. They were operated by an automatic deluge valve, which was actuated by a rate-of-rise detector. The vertical vent was used.

Experiment 3. Loaded in horizontal-storage skeleton racks to provide load-to-vent ratio of $5 \mathrm{lb} / \mathrm{in}^{2}{ }^{2}$, water flow set for $15 \mathrm{gpm}$ per head. At $20 \mathrm{sec}$, first fumes; $22 \mathrm{sec}$, sprinkler deluge valve operated; $45 \mathrm{sec}$, voluminous fumes ; $1 \mathrm{~min} 30 \mathrm{sec}$, pressure $0.15 \mathrm{lb} /$ in $^{2}$ and greater fumes; $3 \mathrm{~min}$ $45 \mathrm{sec}$, fumes nearly ceased; $10 \mathrm{~min}$, water off.

Actual water flow $14.7 \mathrm{gpm}$ per head. Apparent duration of combustion $6 \mathrm{~min}$, automatic camera failed, but visually observed maximum pressure was $0.15 \mathrm{lb} / \mathrm{in}^{2}{ }^{2}$. All film in same vertical stack as igniter can burned out. The only other reels of film burned out were in the stack on either side of the igniter can. Maximum recorded temperature $1,850^{\circ} \mathrm{F}\left(1,010^{\circ} \mathrm{C}\right)$.

Experiment 4. Loaded in horizontal-storage skeleton racks to provide load-to-vent ratio of $5 \mathrm{lb} / \mathrm{in}^{2}$. Asbestos millboard, $3 / 16$ in. thick, was placed to insulate the top, bottom, sides, and rear of each film can in the stack containing the igniter can and in the stack on each side of it. Water flow set for $15 \mathrm{gpm}$ per head. At $10 \mathrm{sec}$, first fumes; $18 \mathrm{sec}$, deluge valve operated and door-trip signal received; 1 min $10 \mathrm{sec}$, fumes out vent; $10 \mathrm{~min}$, still fuming steadily; $16 \mathrm{~min}$, fumes ceased; $16 \mathrm{~min} 30 \mathrm{sec}$, door opened; 18 min $10 \mathrm{sec}$, water off.

Actual water flow 14.8 gpm per head. Apparent duration of combustion about $16 \mathrm{~min}$, maximum recorded pressure $0.03 \mathrm{lb} / \mathrm{in} .^{2}$, maximum recorded temperature $676^{\circ}$ $\mathrm{F}\left(358^{\circ} \mathrm{C}\right)$. On the average, fumes were moderately light. The only film burned out, other than the igniter can, was a full stack adjacent to that immediately opposite the igniter can.

Experiment 6. Loaded in horizontal-storage skeleton racks to provide load-to-vent ratio of $5 \mathrm{lb} / \mathrm{in} .{ }^{2} ; 3 / 16$-in. asbestos millboard used to insulate the top, bottom, sides, and rear of each can in the stack containing the igniter can and in the stack on each side of it. The three central stacks immediately opposite were similarly insulated with $5 / 16$-in. gypsum board. Water flow set for $10 \mathrm{gpm}$ per head. At $19 \mathrm{sec}$, deluge valve operated and door-trip signal received; 45 sec, first fumes; 1 min $45 \mathrm{sec}$, steady fuming; 2 min $45 \mathrm{sec}$, fuming ceased; $10 \mathrm{~min}$, water off on again at $11 \mathrm{~min}$, off at $15 \mathrm{~min} 38 \mathrm{sec}$.

Actual water flow $10.2 \mathrm{gpm}$ per head, maximum recorded pressure $0.10 \mathrm{lb} / \mathrm{in}^{2}$, maximum recorded temperature $1,591^{\circ} \mathrm{F}\left(866^{\circ} \mathrm{C}\right)$. Fumes were of light to moderate intensity, short duration. Nearly all the burned out film was in the rack opposite the igniter. However, the total amount was small.

Group IV. The following are summaries of the observations from experiments without sprinklers. However, the supply pipes remained in the vault and water was circulated through them and discharged outside the vault to protect the pipes 
from the high temperatures anticipated. The deluge and door-trip signal indicators were not connected.

Experiment 10. Loaded in horizontal-storage skeleton racks to provide load-to-vent ratio of $5 \mathrm{lb} / \mathrm{in} .{ }^{2}$. At $20 \mathrm{sec}$, first fumes; $42 \mathrm{sec}$, dense fumes from around door and both vents; 55 sec, vertical vent cover blown off; 1 min 4 sec, fumes from stack burst into flame; $1 \mathrm{~min} 30 \mathrm{sec}, 50 \mathrm{ft}$ flames from stack; 2 min $20 \mathrm{sec}$, flame length down to 10 $\mathrm{ft} ; 2 \mathrm{~min} 35 \mathrm{sec}$, burst of flames at least $50 \mathrm{ft}$ high; $3 \mathrm{~min}$, only slight fumes, no flames.

The film in the vault was completely destroyed. At the height of activity, a few film cans were blown out the stack to an estimated height of $100 \mathrm{ft}$. The maximum recorded temperature was $2,134^{\circ} \mathrm{F} \quad\left(1,168^{\circ} \mathrm{C}\right)$. The temperature indicated by the highest reading thermocouple was over $1,832^{\circ} \mathrm{F}\left(1,000^{\circ} \mathrm{C}\right)$ for a period of $1 \mathrm{~min} 44 \mathrm{sec}$. The maximum recorded pressure was $1.01 \mathrm{lb} / \mathrm{in.}^{2}$. In addition to the flames from the stack, flames issued around the door late in the period of combustion. After the experiment, the door was found to have been warped. The apparent duration of combustion was about $2 \mathrm{~min} 30 \mathrm{sec}$.

Experiment 11. Loaded in horizontal-storage skeleton racks to provide load-to-vent ratio of $7 \mathrm{lb} / \mathrm{in} .^{2}$. At $17 \mathrm{sec}$, first fumes, $3 \overline{5}$ sec, very dense fumes; $1 \mathrm{~min}$, vent cover blown off and fumes burst into flames; $1 \mathrm{~min} 12 \mathrm{sec}$, mercury manometers blown out; $1 \mathrm{~min} 30 \mathrm{sec}$, pressure reduced; 2 min $10 \mathrm{sec}$, only slight flames.

All the film was destroyed. The maximum recorded temperature was $2,088^{\circ} \mathrm{F}\left(1,142^{\circ} \mathrm{C}\right.$. $)$ The gage pressure rose from near zero to a maximum of $18.3 \mathrm{lb} / \mathrm{in}^{2}$ in a few seconds. The manometers were blown out, the maximum being read from a gage. The high pressure was believed due in part to possible jamming of film cans in the vent stack. The maximum flame height was estimated at $70 \mathrm{ft}$ above the top of the stack, somewhat higher than shown in figure 10. Film was blown from the stack to an estimated height of about $500 \mathrm{ft}$.

Experiment 13. Loaded in ICC shipping cases on vertical-storage racks to provide load-to-vent ratio of $7 \mathrm{lb} / \mathrm{in}^{2}$. At 35 sec, first fumes followed immediately by vent lid being blown off; 50 sec, fumes from vent in puffs; 1 min 4 sec, fumes ignited; $1 \mathrm{~min} 30 \mathrm{sec}, 20 \mathrm{ft}$ flames; $50 \mathrm{ft}$ or greater flames from $1 \mathrm{~min} 50$ sec to $2 \min 45$ sec; 4 min, $15 \mathrm{ft}$ flames; 4 min $55 \mathrm{sec}$, sound of burst heard; $6 \mathrm{~min} 20 \mathrm{sec}$, all flaming ceased.

All the film was destroyed. However, the insulated ICC cases retarded the rate at which the film burned. The combustion continued for approximately $6 \mathrm{~min}$, much longer than in the other experiments without sprinklers. The maximum recorded pressure was only $0.35 \mathrm{lb} / \mathrm{in}^{2}$, but this pressure continued for a longer period than previous maxima.

Experiment 1\%. Loaded in vertical-storage skeleton pipe racks to provide load-to-vent ratio of $7 \mathrm{lb} / \mathrm{in}^{2}{ }^{2}$ and load-tovolume ratio of $13.32 \mathrm{lb} / \mathrm{ft}^{3}$, horizontal vent. At $30 \mathrm{sec}$, first fumes; 35 sec, first flames; 40 sec, fumes from around cover of vertical vent; $1 \mathrm{~min} 10 \mathrm{sec}$, flame from horizontal vent $75 \mathrm{ft}$ long and flame from around door and cover on vertical vent; 1 min 15 sec, flames from horizontal vent $100 \mathrm{ft}$ long; 1 min 20 sec, film being blown from vent; $1 \mathrm{~min}$ $40 \mathrm{sec}$, flames only $50 \mathrm{ft}$ long; $2 \mathrm{~min}$, only $25 \mathrm{ft}$; $3 \mathrm{~min} 15$ sec, flames almost ceased.

All the film in the vault was burned. Film was blown through the vent to distances up to $350 \mathrm{ft}$ from the vault and flame length was at least $100 \mathrm{ft}$. The maximum recorded pressure was $3.0 \mathrm{lb} / \mathrm{in}^{2}$ and the maximum recorded temperature exceeded $2,192^{\circ} \mathrm{F}\left(1,200^{\circ} \mathrm{C}\right)$, the full scale of the potentiometer, for a period of $40 \mathrm{sec}$. Figure 13 shows the discharge of flames and film during this experiment.

\subsection{Beltsville Vault Program with Compart- mented Racks}

This portion of the investigation was composed of the film-vault experiments in which sperial compartmented film racks were used. These racks were described in 2.2 a. 'They held much less film than the skeleton racks. 'Therefore, the load to vault-volume ratios were low. However, the vent area was adjusted to give a load-to-vent ratio of $\mathrm{lb} /$ in. $^{2}$ in each experiment. 'The vertical vent was used throughout. The iesults of the experiments are given in groups rather than in numerical order. As stated in section 2, these groups were determined on the basis of the variables, primarily the type of sprinkler used. In order to avoid possible confusion, the group numbers are in continuation of those in 2.

Group $V$. The following are summaries of the experiments in which six $165^{\circ} \mathrm{F}$ standard sprinkler heads were installed.

Experiment 18. Loaded in open-front compartmented racks. Water flow set for $15 \mathrm{gpm}$ per head. At $16 \mathrm{sec}$ deluge-valve signal received; 32 sec, sprinklers operated $43 \mathrm{sec}$, first fumes observed, $1 \mathrm{~min}$, dense fumes; $2 \mathrm{~min}$, very little fumes; 6 min 5 sec, water off.

Actual water flow $\mathbf{1 5 . 6} \mathrm{gpm}$ per head, two heads operated. Maximum recorded pressure and temperature $0.06 \mathrm{lb} / \mathrm{in} .^{2}$ and $1,321^{\circ} \mathrm{F}\left(716^{\circ} \mathrm{C}\right)$, respectively. Apparent duration of combustion less than $2 \mathrm{~min}$. No film other than that in the igniter can burned out.

Experiment 20. Loaded in closed-front compartmented racks. Water flow set for $15 \mathrm{gpm}$ per head. At $32 \mathrm{sec}$, first fumes; $35 \mathrm{sec}$, deluge-valve signal received; $51 \mathrm{sec}$ sprinklers operated; 1 min $30 \mathrm{sec}$, very light fumes from vent and around door; $3 \mathrm{~min}$, fumes from vent only; $5 \mathrm{~min}$ 13 sec, water off.

Actual water flow $16.3 \mathrm{gpm}$ per head, two heads operated. Maximum recorded pressure and temperature $0.07 \mathrm{lb} / \mathrm{in}^{2}$ and $666^{\circ} \mathrm{F}\left(352^{\circ} \mathrm{C}\right)$, respectively. Apparent duration of combustion about 3 min. Only the igniter roll burned. The reel immediately above was slightly damaged by heat as were the doors of a few compartments below. Despite the closed fronts, considerable water entered the compartments and remained there, but none got inside any of the film cans.

Group VI. The following are summaries of experiments in which six $165^{\circ} \mathrm{F}$ spray-type sprinkler heads were installed in a directed-spray system.

Experiment 16. Loaded in open-front compartmented racks. Water-flow valve set full open. At $25 \mathrm{sec}$, first fumes; 35 sec, heavy fumes from around door; $45 \mathrm{sec}$, light fumes from vent; 3 min, light steady fumes from around door; $8 \mathrm{~min}$, fumes decreasing.

For some unknown reason the "igniter" roll of film did not fully ignite but went into a rapid decomposition, which did not cause any recorded vault pressure or heat damage. The maximum recorded temperature of $117^{\circ} \mathrm{F}\left(6 \pm^{\circ} \mathrm{C}\right)$ would not be high enough to canse any of the sprinklers to operate.

Experiment 1\%. Loaded in open-front compartmented racks. Water-flow valve set full open. This was a repeat of experiment 16 with a new igniter roll. It 10 sec. deluge-valve signal received; $2 S$ sec, first fumes and sprinkler operation; 37 sec, dense fumes from rent and door; 2 min 15 sec, decreased fumes; 3 min, practically no funes; 6 min 5 sec, water off.

Actual water flow 17.6 gpm per hesd. four operated. Maximuin recorded pressure and temperature $0.13 \mathrm{lb}$ in.? and $1,738^{\circ} \mathrm{F}\left(948^{\circ} \mathrm{C}\right)$, respectively. Apparent duration of combustion between 2 and 3 min. Sbout one-fourth of the film in the same rack as the igniter eau was slightly damaged by heat. llowever, one-third of the tilm in the opposite rack was either burued out or severely dausged by heat. 
Group VII. The following are summaries of experiments in which six open spray heads were used in a directed system. The deluge valve for the sprinklers was operated manually following a signal caused by the operation of a rate-of-rise detector or smoke detector.

Experiment 14. Loaded in open-front compartmented racks. Water flow set for $15 \mathrm{gpm}$ per head, to be started on rate-of-rise signal. At $20 \mathrm{sec}$, first fumes; $23 \mathrm{sec}$, smoke-detector signal received; 33 sec, deluge valve operated following ratc-of-rise signal; $1 \mathrm{~min}$, most of fumes coming from door: $5 \mathrm{~min} 13 \mathrm{sec}$, water off.

Actual water flow $14.7 \mathrm{gpm}$ per head. Maximum recorded pressure and temperature $0.06 \mathrm{lb} / \mathrm{in}^{2}$ and $536^{\circ} \mathrm{F}$ $\left(280^{\circ} \mathrm{C}\right)$, respectively. The igniter roll was the only film destroyed. Three other rolls were slightly damaged by heat or water.

Experiment 15. Loaded in open-front compartmented racks. Water flow set for $15 \mathrm{gpm}$ per head. Deluge valve to be operated following smoke-detector signal. At 20 sec, flames, fumes, and smoke-detector signal; 24 sec, deluge valve operated, rate-of-rise signal received; 1 min, heavy fumes from around door as vent cover lifted; 5 min 3 sec, water off.

Actual water flow $\mathbf{1 5 . 1} \mathrm{gpm}$ head. Maximum recorded pressure and temperature $0.10 \mathrm{lb} / \mathrm{in}^{2}$ and $1,724^{\circ} \mathrm{F}\left(940^{\circ}\right.$ C), respectively. Seven rolls of film were burned out, six others were slightly damaged by heat in the rack opposite the igniter can, and seven were slightly danaged by heat and three by water in the same rack as the igniter can.

Experiment 19. Loaded in closed-front compartmented racks. Water flow set for $15 \mathrm{gpm}$ per head. The deluge valve was to be operated following rate-of-rise signal. No smoke detector. At 11 sec, sprinklcrs on; $20 \mathrm{sec}$, fumes from door; 1 min, slight fumes from vent; $2 \mathrm{~min}$, very slight fumes from door; $3 \mathrm{~min}$, water off.

Actual water flow $15.2 \mathrm{gpm}$ per head. No recordable pressure, maximum recorded temperature $1,087^{\circ} \mathrm{F}$ $\left(586^{\circ} \mathrm{C}\right)$. The igniter film was burned out, but the film in the compartments immediately above and below were only slightly damaged by heat. No other film was damaged.
Group TIII. No sprinklers were installed in the vault for these experiments. However, a rateof-rise detector was installed to operate a signal, and a smoke meter was installed to determine the fume-density characteristics inside the vault.

Experiment 21. Loaded in closed-front compartmented racks. At $14 \mathrm{sec}$, smoke meter off scale (over 50 -percent reduction of light transmission); $18 \mathrm{sec}$, flash of flame; $22 \mathrm{sec}$, rate-of-rise detector signal, and vent cover displaced; 1 min $10 \mathrm{sec,} \mathrm{first} \mathrm{fumes} \mathrm{outside} \mathrm{vault;} 2 \mathrm{~min}$, fumes from vent and door; $14 \mathrm{~min}$, continued fumes from door; $20 \mathrm{~min}$, slight fumes from vent.

Four cans of film below the igniter can were burned out. The fifth below and the first above the igniter can were slightly damaged by heat. None of the others was affected. The maximum recorded pressure and temperature were $0.09 \mathrm{lb} / \mathrm{in.}^{2}$ and $968^{\circ} \mathrm{F}\left(520^{\circ} \mathrm{C}\right)$, respectively.

Experiment 22. Loaded in closed-front compartmented racks. At $15 \mathrm{sec}$, flash of flame; $18 \mathrm{sec}$, rate-of-rise signal; $1 \mathrm{~min} 25 \mathrm{sec}$, dense fumes from vent; $3 \mathrm{~min} 50 \mathrm{sec}$, vent cover blown off by explosion with flash of flame; 7 min, steady fumes; $18 \mathrm{~min}$, very light fumes.

The smoke meter did not operate because of a clogged filter in the sampling line. The can of film immediately above the igniter can and the six below it were burned out. The seventh below was slightly damaged by heat, but no others were affected. Maximum recorded pressure and temperature were $0.25 \mathrm{lb} / \mathrm{in} .^{2}$ and $1,256^{\circ} \mathrm{F}\left(680^{\circ} \mathrm{C}\right)$, respectively.

Experiment 23. Loaded in open-front compartmented racks. At $11 \mathrm{sec}$, puff of fumes; $14 \mathrm{sec}$, smoke meter off scale; 15 sec, rate-of-rise detector signal received; 35 sec, fumes and flame out vent; 1 min 30 sec, 30 - to 40 -ft flames from vent; 2 min 30 sec, 5 -ft flames; 3 min, flames ceased; $3 \mathrm{~min} 30 \mathrm{sec}$, slight fumes.

All the film was destroyed. Maximum recorded pressure and temperature were $0.95 \mathrm{lb} / \mathrm{in}^{2}{ }^{2}$ and $2,169^{\circ} \mathrm{F}\left(1,187^{\circ} \mathrm{C}\right)$, respectively.

Washington, July 29, 1955. 


\section{BUILDING MATERIALS AND STRUCTURES REPORTS}

[Continued from cover page II]

BMS35

BMS36

BMS37

BMS38

BMS39

BMS40

BMS41

BMS42

BMS43

BMS44

BMIS45

BMS 46

BMS47

BMS48

BMS49

BMIS50

BMIS51

B\IS52

B.IS53

BMS54

BMIS5̃

BMIS56

BMIS57

BMS58

BMIS59

BMIS60

BMS61

BMS62

BMS63

BMIS64

BMIS65

BMS66

BMS67

BMS68

BMS69

BMS70

BMS71

BMS72

BMS73

BMS74

BMS75

BMS76

BMS77

BMS78

BMS79

BMS80

BMS81

BMS82

BMS83

BMS84

BMS85

Stability of Sheathing Papers as Determined by Accelerated Aging

Structural Properties of Wood-Frame Wall, Partition, Floor, and Roof Constructions With "Red Stripe" Lath Sponsoled by The Weston Paper and Manufacturing Co--

Structural Properties of "Palisade Homes" Constructions for Walls, Partitions, and Floors, Sponsored by Palisade Homes.

Structural Properties of Two "Dunstone" Wall Constructions Sponsored by the W. E. Dunn Manufacturing Co

Structural Properties of a Wall Construction of "Pfeifer Units" Sponsored by the Wisconsin Units Co

Structural Properties of a Wall Construction of "Knap Concrete Wall Units" Sponsored by KKnap America, Inc . . . . . . . . . .

Effect of Heating and Cooling on the Permeability of Masonry Walls Insulating Boards Sponsored by The Celotex Corporation

Performance Test of Floor Coverings for Use in Low-Cost Housing: Part 2 Surface Treatment of Steel Prior to Painting

Air Infiltration Through Windows.

Structural Properties of "Scott-Bilt" Prefabricated Sheet-Steel Construction for Walls, Floors, and Roofs Sponsored by The Globe-Wernicke Co Structural Properties of Prefabricated Wood-Frame Constructions for Walls, Partitions, and Floors Sponsored by American Houses, Inc . . .

Structural Properties of "Precision-Built" Frame Wall and Partition Constructions Sponsored by the Homasote Co._.

Metallic Roofing for Low-Cost House Construction

Stability of Fiber Building Boards as Determined by Accelerated Aging

Structural Properties of "Tilecrete Type A" Floor Construction Sponsored by the Tilecrete Co Effect of Ceiling Insulation Upon Summer Comfort
Structural Properties of a Masonry Wall Construction of "Munlock Dry Wall Brick" Sponsored by the Munlock Engineering Co ......

Effect of Soot on the Rating of an Oil-Fired Heating Boiler

A Survey of Humidities in Residences

Roofing in the United States-Results of a Questionnaire...

Strength of Soft-Soldered Joints in Copper Tubing

Properties of Adhesives for Floor Coverings

Strength, Absorption, and Resistance to Laboratory Freezing and Thawing of Building Bricks Produced in the United States

Structural Properties of Two Nonreinforced Monolithic Concrete Wall Constructions --

Structural Properties of a Precast Joist Concrete Floor Construction Sponsored by the Portland Cement Association .

Moisture Condensation in Building Walls.

Solar Heating of Various Surfaces

Methods of Estimating Loads in Plumbing Systems.

Plumbing Manual Structural Properties of "Mu-Steel" Prefabricated Sheet-Steel Constructions for Walls, Partitions, Floors, and Roofs, Sponsored by Herman A. Mugler.

Performance Test for Floor Coverings for Use in Low-Cost Housing: Part 3

Stability of Fiber Sheathing Boards as Determined by Accelerated Aging

Asphalt-Prepared Roll Roofings and Shingles ... . .

Fire Tests of Wood- and Metal-Framed Partitions

Structural Properties of "Precision-Built, Jr." Prefabricated Wood-Frame Wall Construction Sponsored by the Homasote Co

Indentation Characteristics of Floor Coverings._._.

Structural and Heat-Transfer Properties of "U. S. S. Panelbilt" Prefabricated SheetSteel Constructions for Walls, Partitions, and Roofs Sponsored by the Tennessee Coal, Iron \& Railroad Co

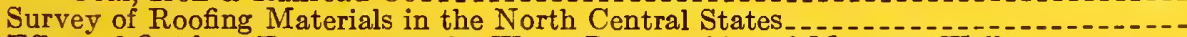

Effect of Outdoor Exposure on the Water Permeability of Masonry Walls.........

Properties and Performance of Fiber Tile Boards

Structural, Heat-Transfer, and Water-Permeability Properties of Five Earth-TTall Constructions

Water-Distributing Systems for Buildings

Performance Test of Floor Coverings for Use in Low-Cost Housing: Part 4

Field Inspectors' Check List for Building Constructions (cloth cover $5 \times 7 \frac{1}{2}$ inches) -- $40 \Leftrightarrow$

Water Permeability of Walls Built of Masonry Units

Strength of Sleeve Joints in Copper Tubing Made With Various Lead-Base Solders... 15e

Survey of Roofing Materials in the South Central States.......

Dimensional Changes of Floor Coverings With Changes in Relative Humidity and Temperature.

"Out of print.

[List continued on cover page IV] 


\section{BUILDING MATERIALS AND STRUCTURES REPORTS}

\section{[Continued from cover page III]}

BMS86 Structural, Heat-Transfer, and Water-Permeability Properties of "Speedbrik" Wall Construction Sponsored by the General Shale Products Corporation.

BMS87 A Method for Developing Specifications for Building Construction-Report of Subcommittee on Specifications of the Central Housing Committee on Research, Design, and Construction .

BMS88

Recommended Building Code Requirements for New Dwelling Construction With Special Reference to War Housing

BMS89 Structural Properties of "Precision-Built, Jr." (Second Construction) Prefabricated Wood-Frame Wall Construction Sponsored by the Homasote Co

BMS90 Structural Properties of "PHC" Prefabricated Wood-Frame Constructions for Walls, Floors, and Roofs Sponsored by the PHC Housing Corporation ........

BMS91

BMS92

BMS93

BMS94

BMS95

BMS96

BMS97

BMS98

BMS99

BMS100

BMS101

BMS102

BMS103

BMS104

BMS105

BMS106

BMS107

BMS108

BMS109

BMS110

BMS111

BMS112

BMS113

BMS114

BMS115

BMS116

BMS117

BMS118

BMS119

BMS120

BMS121

BMS122

BMS123

BMS124

BMS125

BMS126

BMS127

BMS128

BMS129

BMS130

BMS131

BMS132

BMS133

BMS134

BMS135

BMS136

BMS137

BMS138

BMS139

BMS140

BMS141

BMS142

BMS143

BMS144

A Glossary of Housing Terms

Fire-Resistance Classifications of Building Constructions

Accumulation of Moisture in Walls of Frame Construction During Winter Exposure--

"Knap Concrete-Unit" Walls.

Tests of Cement-Water Paints and Other Waterproofings for Unit-Masonry Walls...-

Properties of a Porous Concrete of Cement and Uniform-Sized Gravel...........

Experimental Dry-Wall Construction With Fiber Insulating Board

Physical Properties of Terrazzo Aggregates _...

Structural and Heat-Transfer Properties of "Multiple Box-Girder Plywood Panels" for Walls, Floors, and Roofs

Relative Slipperiness of Floor and Deck Surfaces

Painting Steel

Measurements of Heat Losses From Slab Floors
Structural Properties of Prefabricated Plywood Lightweight Constructions for Walls,

Partitions, Floors, and Roofs Sponsored by the Douglas Fir Plywood Association--

Paint Manual with particular reference to Federal Specifications________._.

Laboratory Observations of Condensation in Wall Specimens.

Building Code Requirements for New Dwelling Construction

Temperature Distribution in a Test Bungalow With Various Heating Devices.....-

Strength of Houses: Application of Engineering Principles to Structural Design --.-

Paints for Exterior Masonry Walls.

Performance of a Coal-Fired Boiler Converted to Oil

Properties of Some Lightweight-Aggregate Concretes With and Without an Air-

Entraining Admixture.

Fire Resistance of Structural Clay Tile Partitions

Temperature in a Test Bungalow With Some Radiant and Jacketed Space Heaters.-.

A Study of a Baseboard Convector Heating System in a Test Bungalow

Preparation and Revision of Building Codes

Fire Resistance of Walls of Lightweight Aggregate Concrete Masonry Units.

Stack Venting of Plumbing Fixtures

Wet Venting of Plumbing Fixtures

Fire Resistance of Walls of Gravel-Aggregate Concrete Masonry Units.

Investigation of Failures of White-Coat Plasters

Physical Properties of Some Samples of Asbestos-Cement Siding

Fire Tests of Wood-Framed Walls and Partitions With Asbestos-Cement Facings.-.--

Fire Tests of Steel Columns Protected With Siliceous Aggregate Concrete

Stone Exposure Test Wall

The Self-Siphonage of Fixture Traps

Effect of Aging on the Soundness of Regularly Hydrated Dolomitic Lime Putties.-.-

Atmospheric Exposure Tests of Nailed Sheet Metal Building Materials.............

Fire Endurance of Shutters for Moving-Stairway Openings _. .

Methods and Equipment for Testing Printed-Enamel Felt-Base Floor Covering

Fire Tests of Gunite Slabs and Partitions .

Capacities of Plumbing Stacks in Buildings.

Live Loads on Floors in Buildings.

Fire Resistance of Concrete Floors...

Fire Tests of Steel Columns Encased With Gypsum Lath and Plaster.

Properties of Cavity Walls . .

Influence of the Wash From Bronze on the Weathering of Marble

Effect of Edge Insulation Upon Temperature and Condensation on Concrete-Slab

Floors - -

Studies of Stone-Setting $\mathbf{M}$ Tortars

Selected Bibliography on Building Construction and Maintenance

Ceilings

Frost Closure of Roof Vents.

Fire Tests of Brick Walls

Supplement tound Insulation of Wall and Floor Constructions

BMS145 Fire Effects and Fire Control in Nitrocellulose Photographic-Film Storage

- Out of print. 